\title{
Insurgent Urbanism, Citizenship and Surveillance in Kampala City: Implications for Urban Policy in Uganda
}

\author{
Paul Isolo Mukwaya \\ Department of Geography, Geo-Informatics and Climatic Sciences, Makerere University, Kampala, Uganda \\ Email:pmukwaya@gmail.com
}

Received 20 March 2016; accepted 25 June 2016; published 29 June 2016

Copyright (C) 2016 by author and Scientific Research Publishing Inc.

This work is licensed under the Creative Commons Attribution International License (CC BY). http://creativecommons.org/licenses/by/4.0/

(c) (i) Open Access

\begin{abstract}
A great deal of work has been done on the nature of rights and the definitions of citizenship. However, little work has been done that explores how people perceive their citizenship rights and how they act on these perceptions especially in growing cities. High and low intensity protests have inscribed their presence and voice in Kampala city's streets, thereby becoming integral components of the city landscape. The paper uses critical urban theory, insurgent urbanism and citizenship as its conceptual framework to: 1) examine the terrain of struggle and militancy and, how Kampala residents engage with the state beyond formal processes; and, 2) assess government surveillance actions aimed at (de) constructing of citizenship in the city. The paper illuminates these questions and elaborates the notion of insurgent urbanism using Mabira forest demonstrations, September 2009 Buganda riots, and Walk-to-Work' (W2W) protests in Kampala City. The paper argues that the currents of militancy are very active across the city and the institutionalization and planning for insurgent claims and associated government responses in the broader urban policy terrain across the country.
\end{abstract}

\section{Keywords}

Citizenship, Insurgency, Surveillance, Space, Policy, Kampala

\section{Introduction}

The city has become a defining life space for most of the world's population with over $50 \%$ classified as urban and a further $61 \%$ becoming urban by 2025 . In the early $21^{\text {st }}$ century, three types of urban realities were emerging. The first was labeled a "flirtual (real-and-imagined) mobile city"; simultaneously t/here and re/present (Soja 
1996). The second urban reality is labeled a "blored (bloody-boring-luring) walled city"; the famous city of quartz (Davis 1992) and the walled and framed edge city (Dear and Flusty 1998). The third urban reality is the "DISPER (ATE) city"; a glocal date/hate network metropolis (Sassen 2001). In each of these cities, urban conflicts are not a new phenomenon (Isin, 2000). These days it is not hard to enumerate all manner of urban discontents and anxieties, as well as excitements, in the midst of even more rapid urban transformations (Harvey, 2012).

Modern cities had already become the sites of revolutionary politics, where the deeper currents of social and political change rise to the surface (Harvey, 2012) and these have brought back the status of citizenship and rights to the city in the spotlight (Ansley, 2010). The likelihood of urban insurgency (i.e. guerrilla or terrorist) warfare in cities is increasing as the dual demographic trends of rapid population growth and urbanization continue to challenge the face of the developing world (Taw and Hoffman, 2005). Cities have become the frontline for struggles; the milieu for a whole range of new types of conflicts, such as asymmetric war and urban violence (Sassen, 2010). They are sites where alternative practices, resistance and battles for control of urban space are waged (Blomley, 1997). The uprisings in the Arab world, the neighborhood protests in China's major cities, Latin America's piqueteros and poor people demonstrating with pots and pans-are all vehicles where people make social and political claims (Sassen, 2011; Harvey, 2012) to reassert their collective right to the city (Harvey, 2012). The anti-gentrification struggles and demonstrations against police brutality in US cities, the 200,000 people marching in Tel Aviv-not to bring down the government, but to ask for access to housing and jobs; the indignados in Spain demonstrating peacefully for jobs and social services and the 1300-kilometer march to Brussels; are movements that seek to engage the powerful, not just protest against them (Sassen, 2011; Harvey, 2012).

As this will be developed later, this paper considers an array of civil, political, social, and economic rights, including the rights to shelter, clean water, sewage discharge, education, and basic health-in what Lefebvre (1991) referred to as "the right to the city." The right to the city is, therefore, far more than a right of individuals or group access to the resources that the city embodies: it is a right to change and reinvent the city. It is, moreover, a collective rather than an individual right, since reinventing the city inevitably depends upon the exercise of a collective power over the processes of urbanization (Harvey, 2012). The struggles are performed not only in the high courts of justice and ministerial corridors of government institutions but also in the streets of cities, the squatter camps, and the everyday life spaces of those excluded from state's citizenship. The protagonists of this contest use non-formalized channels, create new spaces of citizenship, and improvise and invent innovative practices, all of which attract a captive constituency (Miraftab \& Wills, 2005).

Urban groups are emerging as contenders for power in East Africa as their capacity is extended by the acquisition of information: information about alternative conceptions of politics and justice; information which can challenge a government's version of events and indeed its very legitimacy; and information about other individuals' aspirations and critiques. As these groups mobilize, scenes of conflict between riot police and demonstrators are a familiar feature (Baker, 2015). This paper explores the urban insurgency debate by: 1) examining the terrain of struggle and how Kampala residents engage with the state; 2) reviewing surveillance actions aimed at (de) constructing citizenship and rights to the city. The rest of the paper unfolds as follows. Section 2 presents the theoretical framework against which the whole paper is anchored. Section 3 delves into the city setting in which the paper is situated and outlines the general trends within which urban policy operates. Although the whole intensions of the paper feed into the broader urban environment in Uganda, the focus of the paper is on Kampala City, the largest commercial and administrative capital of Uganda. The city is not only a testing ground for Uganda urban policy ideals but also for urban management on a broader scale. Section 4 discusses the data collection methods that were employed. Section 5 presents the results and finally Section 6 draws together the main findings into their wider urban policy implications for Uganda.

\section{Critical Urban Theory, Insurgent Urbanism and Citizenship}

The paper is anchored in critical urban theory and applies insurgent urbanism, a concept first introduced by Holston (1998) to explore the terrain of struggle and how Kampala residents engage with the state. The notions of critical urban theory have determinate social-theoretical content that is derived from various strands of Enlightenment and post-Enlightenment social philosophy, not least within the work of Hegel, Marx and the Western Marxian tradition (Calhoun, 1995). Brenner (2009) as concerned with: 1) analysis of the systemic, yet his- 
torically specific, intersections between capitalism and urbanization processes; 2) the changing balance of social forces, power relations, socio-spatial inequalities and political-institutional arrangements that shape, and are in turn shaped by, the evolution of capitalist urbanization; 3) exposing the marginalization, exclusions and injustices (whether of class, ethnicity, "race", gender, sexuality, nationality or otherwise) that are inscribed and naturalized within existing urban configurations; 4) deciphering the contradictions, crisis tendencies and lines of potential or actual conflict within contemporary cities, and on this basis, 5) demarcating and politicizing the strategically essential possibilities for more progressive, socially just, emancipatory and sustainable formations of urban life. Critical urban theory emphasizes the politically and ideologically mediated, socially contested and therefore malleable character of urban space-that is, its continual (re) construction as a site, medium and outcome of historically specific relations of social power. Critical urban theory is thus grounded on an antagonistic relationship not only to inherited urban knowledge, but more generally, to existing urban formations. It insists that another, more democratic, socially just and sustainable form of urbanization is possible, even if such possibilities are currently being suppressed through dominant institutional arrangements, practices and ideologies (Brenner, 2009).

Citizenship means different things to different people but it has become a crucial weapon, not only in the struggle against social and economic exclusion and inequality but - most importantly —in the widening of dominant conceptions of politics itself and social organization (Alvarez, Dagnino, \& Escobar 1998). These struggles constitute what is referred to as citizenship; the foundational debates about political association or the purposes for which people agree to deal with collective affairs. The status of citizen denotes a basic role for people as self-directed actors in a political context, and is often distinguished from "subject," which implies a more passive and subordinate status (Clancy, 2014). Thus, the redefinition of citizenship undertaken by social movements, to confront the existing boundaries of what is to be defined as the political arena: its participants, institutions, processes, agenda and scope (Alvarez et al., 1998). Re-conceptualizing the notion of citizenship, and shifting its center from the state to the people, and stressing a pluralist model (Young, 1990) has led to a plethora of new definitions of citizenship, including participatory citizenship, inclusive citizenship (Kabeer, 2002), active citizenship (Lister, 1997), and citizenship from below or insurgent citizenship (Holston, 1998). These definitions signify an alternative conceptualization of citizenship, in which new meanings, agencies, and practices of citizenship are articulated. In this alternative model, practices of citizenship extend beyond taking up invitations to participate in what Cornwall (2002) calls invited spaces of citizenship that extend to forms of action that citizens innovate to create their own opportunities and terms of engagement. Miraftab (2005), referring to these alternative spaces of participation as invented spaces of citizenship, has underlined the significance of expanding the arenas of practicing citizenship to include both invited and invented spaces of citizenship.

The use of the term insurgent practice is a derivative of Holston's (1995) insurgent citizenship, representing a reaction to the modernist spaces that physically dominate cities today. Insurgent citizenship in this vein directly challenges the heart of the belief of the modernist, utopian political project that the state is the only legitimate source of citizenship rights and practices by claiming new and other sources rooted in the present, and asserting their legitimacy (Lamarca, 2010). The city is not a neutral container but a political space in which meaning of citizenship is daily contested and as Holston argues, everyone should take seriously the insurgent practice because they reflect the reality of contemporary urban life (Knudsen, 2007). For Kampala City's case, insurgent practice is sued here as laying claims to urban spaces, to assert new forms of identity and ways of being in the city; which ultimately resonates with the lived spaces and realities of urban living. Insurgent urbanism is an interesting way of looking at how everyday spatial practices and manipulations can lead to new discourses of citizenship (Knudsen, 2007). Holston (1998) states that such insurgent forms are found in both grassroots mobilization and in everyday practices that in a variety of ways empower, parody, derail or subvert state agendas, and thus are fundamentally found in struggles over what it means to be a member of the modern state, or a citizen.

Insurgent practice is specifically defined here as the process of making claims towards inclusive and substantive citizenship rights and towards achieving the right to the city (Lamarca, 2010). Furthermore it finds resonance with one of Castells's (1983) notions of urban social change as a process where new urban meaning is produced as social movements or mobilizations impose a new urban meaning contrary to the institutionalized one and against the interests of the dominant powers. Insurgent practice is connected to claims emerging from marginalized and oppressed groups, fundamentally seeking to transform power dynamics and relations in the city (Lamarca, 2010). Foucault (1998) insists that where there is power, there is resistance. Since planning relies on power to mould and dominate urban spaces, it can be argued that where there is planning there is resistance. 
The phrase "Right to the City" is attributed to Lefebvre in the late sixties, when social movements were springing up all over the place, very visibly in Paris, claiming rights to use the city, live in the city, work in the city, and agitate in the city, in peace. It was a radical, indeed revolutionary, phrase: people had the right to determine their own environment and living conditions, and neither government nor any other powers had the right to tell them what they could or could not do (Marcuse, 2005). Scholars that believe in this approach consider that the production of urban space is achieved by daily struggles and mobilization from below. The other interpretation of the right to the city led by scholars such as Parnel and Pieterse (2010) define it as a collection of rights in the city. However, according to Zerah, Lama-Rewal, Dupont and Chaudhuri (2011), the right to the city is equivocal on at least three points. First, it refers, at the same time, to entitlements and to claims, that is, to the domain of the legal and to that of the moral. It is concerned with existing rights (such as the right to vote in elections) but also with claimed rights (such as the right to public transport). The second is the right to live in the city, to work in the city, to move in the city etc. This remains formal as long as the city is not made affordable (focus on housing), practicable and accessible (focus on transport) safe (focus on street lights, police, etc.) and livable (focus on urban services). The third one is the right to public policies and political participation (in a broad sense) to enable better access to, and use of, the city (Zerah et al. 2011).

Nemeth (2010) finds that three interrelated entitlements comprise the "right to the city": the right to access physical urban space; the right to be social, to express oneself and interact with others; and the right to representation, belonging and citizenship. The first right simply denotes the right to be in public space, to occupy and inhabit it (Marcuse, 2005). The second right is the ability to live a cosmopolitan lifestyle, one that provides the option to engage in unmediated interaction or to retreat into introspective anonymity (Lofland, 2000). This right implies the change to lead an urbane, full, diverse life (Marcuse, 2005) that finds renewed centrality in places of encounter and exchange (Lefebvre, cited in Mitchell, 2003). The third right involves the ability to actively produce space and determine one's own vision of the good life (Young, 1990). This right entails opportunities for representation, participation and appropriation, and involves meaningful access to decision making channels (Lefebvre, 1968).

\section{Selected Studies on Urban Insurgency in Kampala City}

Post-2006 Uganda has created "bastions of protest movements" and the sites of urban insurgency in Kampala City have proliferated. Unprecedented levels of popular protests from several social groupings (Golooba-Mutebi \& Hickey, 2013) have characterized this period including the micro-politics of work (markets, taxi parks, shops, etc), schools/universities, civil society organizations, communities and neighborhoods, political parties, women activists, youth groups, lawyers, monarchists, civil servants, and human rights activists. These groups have united not only in their opposition to government policies, but also, in contesting the established parties' monopoly to articulate socio-economic and political interests and demand political reform.

Academic scholarship on urban protest movements in Uganda is however limited except for media coverage and political statements. Available scholarly evidence on protests in urban areas in Uganda is dated (e.g. Thompson, 1992), and protests were seen in the context of electioneering and political contestations (e.g. Conroy-Krutz \& Logan, 2012; Helle, Makara, \& Skage, 2011; Helle \& Rakner, 2014; Mulumba, 2011; Tabachnik, 2011; Titeca \& Onyango 2012); and, structural transformation challenges across the country (e.g. GoloobaMutebi \& Hickey, 2013; Kjaer \& Katusiimeh, 2012). Izama \& Wilkerson (2011) and Mbazira (2013) describe the events surrounding the W2W protests across the country and the government responses to them. He observed that protests arose from the loss of confidence in the government because of its failure to meet the needs of the people, in spite of promises to do so.

Baker (2015) offers an explanation of the continuation of forceful tactics against political protest in a context of changing methods of information gathering, organization and mobilization by urban activists resulting from their access to internet and communication technology. The paper observes that the regime is caught between legally allowing protest and yet, conscious of their fragility, determined to crush opposition and the military leadership in Uganda relies heavily on continued police violence. The paper concludes that: 1) failure of the police to adapt their public order policing to the new protest environment leaves them increasingly ineffective and unpopular; 2) it is likely to provoke an escalation of violence and may both undermine the legitimacy of the regime and reverse their attempts to open political space that justified their rebellions against former autocracies; and, 3) the regime in Uganda is facing rising contestation and diminishing support as urban groups, equipped 
with new resources, particularly easily received and transmitted information, seek access to the polity.

Goodfellow (2011) on the other hand alludes to the fact that forms of popular participation in urban affairs in Uganda are institutionalized through informal political processes. He argues that the regular mobilization of urban social and economic groups into protests and violent riots has institutionalized a politics of "noise". As a response, legal maneuvers linked to the rise in urban based protests and riots have often become violent and resulted in aggressive crackdowns, violence and institutional repression in order to maintain systemic power (Goodfellow, 2014; Vasher, 2011; Warigia \& Camp, 2013). On political violence in Uganda, Kakuba (2015) recommends that a conducive and just socio-economic and political environment for promoting political trust and tolerance is important.

\section{The Setting: Kampala City}

The paper uses Kampala City to illustrate the terrain of struggle for city residents. The city is the major administrative and commercial centre of Uganda. Kampala City dominates the urban landscape accounting for one third of Uganda's urban population. Greater Kampala boasts of population of 3.5 million and is growing fast, both on account of redevelopment within the city and expansion on the periphery (World Bank, 2015). The city has recorded the highest rates of population growth and if current patterns of growth continue, Kampala will become a megacity with a population of more than 10 million in the next 20 years (World Bank, 2015). This growth is not influenced by natural rate of increase, but rather rural urban migration where most people migrate to the city for employment opportunities, spouses, better standard of living and services, and security while others have migrated due to the loss of their "bread winners", peer influence, and loss of land in rural areas (Avuni, 2011). While accurate data on the distribution of economic activity in the city are not available, it is estimated that about $80 \%$ of the country's industrial and services sectors are located in the city. The economic future of Uganda is thus intrinsically tied to the performance of the city as a locus of productive activity and investment. Protests have increasingly taken on an urban character across the country but I chose to explore activities in Kampala City because:

For the last five years the Kampala City has developed as the hotspot for protest movements in the country. The city evolved into a hive of political activity and popular mobilization; and this presented the nation's capital as the perfect setting for examining the roots of all the political contestations that were visible across the country. A global annual survey showed a heightened sense of socio-economic insecurity in most parts of the world and the Civil Unrest Index given by Bender (2014) placed Uganda in the high risk category. Kalyegira (2011a, 2011b) reports that 2011 was one of the most difficult years ever for the average Ugandan. The only tougher years were 1979 and 1980, following the Tanzania-Uganda war, and 1976-1977, when a western led economic boycott and a financial sabotage by anti-Amin guerrillas crippled the economy (Kalyegira, 2011a; 2011b). Two other traditions of political action in recent history included the popular struggles involving the "Bana ba Kintu" strikes and boycotts of 1945 and 1949, the "Twagala Lule" demonstrations of 1980, in Buganda, as well as taking of power by armed guerrillas (Mamdani, 2012).

Several groups find Kampala City an appropriate place to brings government institutions to account in what Goodfellow (2011) describes as the formal and informal but highly public and disruptive processes that characterize the city's political life. As it became evident legal demonstrations have been less effective while rioting was more effective to win further attention and concessions from government (Goodfellow, 2011). The longest protests and riots took place at a time when the government renewed its policy attention to urban areas across the country including Kampala City. The central government had just taken over the administration of Kampala City to create the Kampala City Capital Authority that was aimed at bringing an "urban renaissance" to the city and give it a fresh start after government reconstituting the city into the Kampala Capital City Authority. In a sense, rioting has been institutionalized; as it forms part of the "rules of the game" of state-society interaction in Kampala City. In any case, the fact remains that Kampala's streets are becoming the battleground where an economically marginalized and politically frustrated opposition flexes its muscles against a government keen on deploying instruments of state violence to quell popular protests (Kock, 2011). I believed that Kampala City's serves as a useful platform to explore insurgent urbanisms and other urban authorities across the country could draw from Kampala's past experiences, as well as those of other cities around the globe to chart a new future for their citizens.

Concentration is given to particular actions in Kampala City to illuminate the processes and reasons whyh 
such campaigns are created. Lehman-Wilzig and Ungar (1985) indicate that the use of newspaper reports constitutes the generally accepted mode of gathering data on protest and socially disruptive events. Access to newspaper reports over the 2006-2016 period was crucial for identifying the major protests movements as well as the strategies and decisions of the individuals and groups involved. I worked back and forth document archives to flesh out the stories behind official correspondence and reports, and files to check and corroborate information. I analyzed this case largely by document analysis and this constituted the following elements:

1) Reviews of Kampala City urban policy framework and procedures and how they influence urban protests by studying important moments in the Kampala City Capital Authority decision making process, i.e., council meetings and other forums in which the different stakeholders interacted.

2) Collation, scrutiny and analysis of other policy documents, bills/acts and press statements, manuals, newspaper articles and blog posts. Some of the events and protest movements were reported online and captured live by electronic media especially television stations. It was therefore necessary to follow these events and reports on the newspaper, event organizers websites and blog postings. For example, information at Activists for Change (A4C) at http://activists4change.blogspot.com, www.williamkituuka.blogspot.com,

http://theafricanist.blogspot.ug/2011/05/walk-to-work-campaign.html, www.observer.ug, www.monitor.co.ug, www.ugandaspeaks.wordpress.com, www.fdcuganda.org, www.ugandacorrespondent.com, www.independent.co.ug and www.kashambuzi.com provided background materials to illuminate the issues of interest in this paper.

\section{Waves of Protest and Construction of Citizenship}

It is possible to identify distinct phases of urban protest that have swept the country and more specifically Kampala City. For a long time, urban Uganda didn't have a well-established culture of expression of public political discontent (see for example, Bratton \& van de Walle, 1992) but events following the 2011 elections left behind a new political actor in Uganda: a self-confident and politically active urban protest and militant culture. Most Ugandans have now started to understand that their collective power if harnessed properly is capable of causing change. Although, reactions to the protest movements in Kampala City were generally predictable, with the NRM's or "law and order" interpretations predominating, the protest movements have essentially been an outburst of anger and resentment of Ugandans against the government and this can be pointed to a number of events and crises, which according to Benyon \& Solomos (1988) result in frustrated expectations, cumulative disappointment and increasing resentment.

Figure 1 shows the number of urban social disorder movements in Kampala City since 1964. The figure

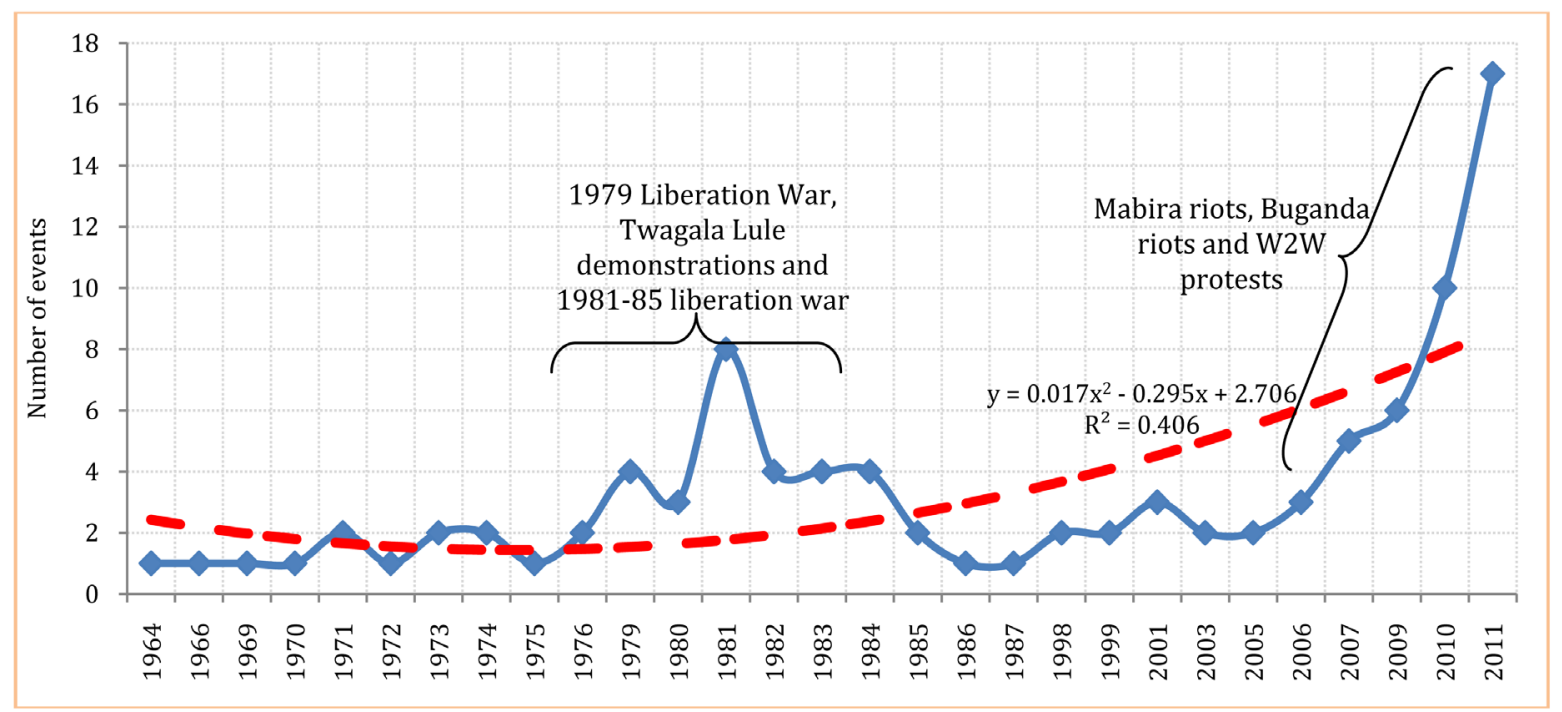

Figure 1. Number of urban social disorder movements in Kampala City (1960-2011). Source: 1964-2005 and 2006 -2011 data were derived from http://www.prio.no/CSCW/Datasets/Economic-and-Socio-Demographic/Urban-Social-Disturbance-in-Africa-and-Asia/ [29 January 2016] and newspaper archives respectively. 
shows that three periods stood strongly; i.e. 1979-1984, 2006-2009 and 2011. Between 2006 and 2011, the number of protest events in Kampala City rose by $1600 \%$. Ostby (2010) reports ten ${ }^{1}$ urban social disorder events as having occurred in Kampala between 1986 and 2006. These have dramatically increased since 2006 and reviews of newspaper reports suggest that between 2006 and 2011, at least 27 protests were recorded in various areas in the city. These estimates may be higher in Uganda Police records and since the beginning of 2012; it appears that the protests are increasing.

While the government increasingly sought to de-legitimate protest, its policies exacerbated the citizens' discontent and led to highly politicized anti-government orientations. The paper uses three examples to frame urban insurgency in Kampala City. Protests in Kampala City have been interpreted in contrasting ways but the examples given in the paper give illustrations that demonstrations and riots have become the "normal" mode of exchange through which urban-dwellers engage with the state. The paper argues that spaces of urban citizenship and expression of protest since 2005 can largely be discerned to fall under three distinct but related movements and these include:

1) The Mabira Forest protest (2006-2007);

2) The September (Buganda) 2009 riots;

3) Walk to Work (W2W) and related protests (2010-To date).

\subsection{Mabira Forest Protest Movement (2006-2007)}

Ugandans took to the streets in 2007 to demonstrate against President Museveni's government's move to give away parts of Mabira Forest to Sugar Corporation of Ugandan Limited (SCOUL). The secrecy surrounding the giveaway, the timing of the announcement (shortly after the 2006 elections), and the enormous economic value of the public asset involved led to rumors of collusion between Uganda's most politically powerful man and one of its most wealthy. Led by two Members of Parliament, Beatrice Anywar and John Ken Lukyamuzi, local environmental civil society organizations, a loose coalition of national and international institutions and actors, including trade and ethnic associations, Buganda kingdom, church groups, prominent academics, political opposition, media figures, multilateral governance institutions, transnational environmental networks and donor countries a spirited fight dubbed "Save Mabira Activism", was organized to fight the giveaway. Even when the forest is located over 60 kilometers away from Kampala City, several thousands of Ugandans poured to the streets of Kampala City and the confrontations with the security forces degenerated into violent street riots that claimed the lives of several people.

President Yoweri Museveni's insistence on giving away part of the forest to SCOUL (Nampewo, 2013; Honig, 2014) was a decision that continues to surprise and irk his enemies and allies alike. There was a lot of talk that Museveni's strong stand in wanting to give away Mabira forest was not connected to sugar production per se. An extended litany of reasons for the giveaway is given by Museveni (2007) and also captured by Akaki (2011). However, a senior Forum for Democratic Change (FDC) official added a fresh twist, also captured by Kjaer \& Katusiimeh (2012) to the brewing battle for Mabira by suggesting that President Museveni's ruling NRM party received unspecified amounts of money from the sugar company to fund its 2006 election campaigns for which it now felt indebted. Otim (2011) ably captured the FDC message;

They were trying to fulfill their part of the deal by sacrificing a very important resource. In fact, one gentleman claiming to be a security operative told UGPulse that it was suspected Museveni promised to give Mehta part of Mabira forest for the support Mehta provided to Museveni and NRM since the start of the guerilla way back in 1981. The businessman had been patient, waiting for the Promised Land to be given to him and it had reached that time when the president felt he should deliver on that promise.

What the government may not have anticipated was how fast public opposition to the SCOUL giveaway would congeal into an effective counterforce (Child, 2009). Without clear leadership or strategic engagement, the spontaneity of discrete discourses coming from an array of significant segments of actors to save the forest, was striking. This compelled the Museveni government to backtrack on a forest giveaway that it had fought hard to push through (Child, 2009; Honig, 2014). In what has been called an astonishing groundswell of public reaction and an iconic symbol of civil society action, the normally parochial politics of the environment emerged on

\footnotetext{
${ }^{1}$ The data are compiled from electronic news reports in the Keesing's Record of World Events and cover different forms of both violent and non-violent politically motivated disorder, including demonstrations, rioting, terrorism and armed conflict.
} 
an expanded political terrain.

The widespread use of internet and other electronic information technologies was an important tool during the early stages of the protest for disseminating information and organizing resistance, and ultimately led to what has been called "one of Africa's first grassroots modern ecological protest campaigns" (Child, 2009). The campaign to save the forest was indicative of African environmental struggles in terms of its heterogeneous civil society composition and ambiguous commitment to conservation, yet it also stood out as a powerful demonstration of how civil society movements that ostensibly championed the environment would also nurture more radical demands for democratic accountability (Child, 2009). Environmental NGOs sent out news alerts to their supporters and published informational web pages, while individual activists published ample literature on their personal blog spaces, emails and SMS text messages. The largest cyber expression of public opposition appeared on the Save Mabira Forest Petition which was launched in September 2006 and within a month had recorded several thousands of signatures per day.

Less sophisticated forms of communication were also employed by activists, including the organization of public meetings, and the distribution of flyers and other "Save Mabira" paraphernalia, including T-shirts, calendars and bumper stickers. Outside of environmental NGOs, students were among the vanguard of the protest movement. Only a month after the giveaway became public knowledge, 300 students from Makerere University marched through the city with a brass band leading the way to the Parliament buildings where they stopped to deliver their own petition. Because of the early public support for the campaign, media coverage intensified over time. By April 2007, it was virtually impossible for an urban Ugandan to pass through a single day without hearing, seeing or reading a radio, TV or newspaper account of Mabira related events (Child, 2009).

\subsection{Buganda Riots (2008-2009)}

The Kingdom of Buganda ${ }^{2}$ and its monarch, the Kabaka, vis-à-vis the rest of the country, is a fault line that shapes Uganda's politics (Barkan, 2011). The Ganda reside in south central Uganda along the shores of Lake Victoria, an area that includes the capital city of Kampala. In a country where 87 percent of the population resides in the rural areas, they distinguish themselves as the most urbanized and educated ethnic group (Barkan, 2011). Although their dominance today is less pronounced, a continued political issue and the basis of political mobilization throughout the country's history has been the debate about the relative autonomy granted to the Kingdom of Buganda and other traditional kingdoms within the larger Ugandan state (Barkan, 2011).

Competing explanations of the underlying drivers of the Buganda riots are ably captured by MRT (2009), Suransky, Kooster, \& Seela (2009) and the International Crisis Group (2012). Previous attempts by the Kabaka to visit other parts of Buganda kingdom Nakasongola in 2008 were stopped by government claiming that it could not protect him. Kingdom ministers then announced he would visit Kayunga in September 2009. Mengo (the seat of Buganda kingdom government) opposes Museveni on the balkanization of Buganda Kingdom through the creation of sub-ethnic districts. Mengo was infuriated by what it perceived as Museveni's determination to undermine Buganda's political influence, to demolish the glory of Buganda kingdom and to deny it Federo while openly supporting non-Baganda groups and individual interests against Buganda (Guweddeko, 2013). Frictions simmered between the Kabaka of Buganda Ronald Mutebi, the central government and the leader of the Banyala exploded into bloody violence when on an advance trip, Buganda's Katikiro (Prime Minister) Walusimbi and other ministers were blocked by armed police and the army from traveling to Kayunga (Suransky et al., 2009; Izama \& Wilkerson, 2011; Vasher, 2011) in preparation of the Kabaka’s visit for the National Youth Day celebrations two days later.

Leaders of the Banyala ethnic group in Kayunga ${ }^{3}$ had opposed the visit (HRW, 2009; Vasher, 2011) and gov-

\footnotetext{
${ }^{2}$ The kingdom is the most powerful, best-organized and most populous (Vasher, 2011) of Uganda's four traditional kingdoms and it claims a proud 600-year history. Its traditional lands include most of Kampala and the surrounding districts. The kingdom rules over the Baganda people. In 1963, the post-colonial constitution formally recognized the power of the traditional kings in a federal system. The kingdoms were later abolished in 1966 and in what many say was a calculated political gamble, the current President Yoweri Museveni decided to restore the monarchy in 1993, but only as a cultural institution under central authority. Of Uganda's four historical kingdoms which were restored in 1993, Buganda is by far the most popular among its subjects and, from the ruling party's viewpoint, the most dangerous threat to the National Resistance Movement (NRM)'s political hegemony. The kingdom has a constitutional monarchy, a local parliament, regional assemblies and, crucially, about $17 \%$ of the Ugandan population (Economist, 2009).

${ }^{3}$ Though the district is in Buganda, some members of the sub-ethnic group in the district, known as the Banyala had announced, unilaterally, secession from Buganda, his presence might spark violence (MRT, 2009; Conroy-Krutz \& Logan, 2012; Vasher, 2011) and wanted him to get permission from their leader, Capt Baker Kimeze, before he could make the tour. Many believe that Capt. Baker Kimeze, a former army officer, is a "government puppet” created to oppose the Buganda Kingdom (Asiimwe, 2009).
} 
ernment authorities for fearing violence denied the King Ronald Muwenda Mutebi II to visit his subjects in the district (Kibanja, Kajumba, \& Johnson, 2012) and reassert authority over his territory. The Ssabanyala insisted the Kabaka should inform him officially first: short of which was bloodshed, but Museveni insisted on two conditions for the visit: that both cultural groups meet with government to negotiate the trip, and Buganda Kingdom radio station; Central Broadcasting Service (CBS) stop criticizing the NRM. Since these terms were tantamount to capitulation, Buganda officials refused to budge (Vasher, 2011; International Crisis Group, 2012). When the Kabaka declined to meet Captain Kimeze, the government stepped in apparently to protect the interests of the Banyala minority group (Asiimwe, 2009).

When it appeared that the Kabaka was determined to visit Kayunga no matter the odds, the army further surrounded his palace in Kireka (a suburb of Kampala City) on the night of September 12, 2009 (Independent, 2010). The government's actions and perceived insult to the Kabaka united the Buganda youth against the central government (Conroy-Krutz \& Logan, 2012; Vasher, 2011). The Kabaka’s supporters took to the streets in protest (Conroy-Krutz \& Logan, 2012; HRW, 2014), provoking a backlash from security forces. The riots; christened the Buganda riots and other acts of resistance were epic in length and intensity as hundreds of the king's supporters rampaged through the streets of Kampala, setting up barricades, looting shops and fighting running battles with police. The MRT (2009) captured moments of the riots as;

In the early stages of the demonstrations on September 10, some protesters resorted to violence in some areas of Kampala, burning at least five cars, one passenger bus, and one delivery truck, blocking some main roads with burning tires and debris, looting shops, and throwing rocks at police and members of the armed forces. In Nateete, protesters burned a police station. In Bwaise, a factory was set on fire. No one was reported injured in either fire, and local hospitals did not report any burn victims.

A number of disturbing urban policy realities emerged during the Buganda riots. First, the geographical spread, breadth and diffusion of the riots was like a wildfire and this came as a complete surprise to government, the security forces and the general public. Unrest in previous years had centered on Kampala's Central Business District and had not extended into the populous residential neighborhoods (MRT, 2009) of Bwaise, Natete, Ntinda, Kisenyi, Kasubi, etc. However, three days of total city paralysis and effective closure of economic activity in the city were followed by the spread of riots to other towns across the country including Mukono, Mpigi, Kayunga and Masaka (Kibanja et al., 2012). Museveni’s presidency, for all its successes, has performed poorly in promoting the pre-eminence of state institutions in the face of rival institutional frameworks anchored in regionally and ethnically based communities (Lindemann, 2010). The riots were a sign that the state's exclusionary practices towards Baganda elites may be alienating the wider population (Goodfellow, 2010).

The riots revealed that Baganda youths had become radicalized and militant over the years, and could easily be mobilized to challenge the state. The profile of the stone throwing, tyre burning youth on the streets of Kampala and the suburbs was easy to sketch. A larger majority of the rioters was under 25 years of age, not very educated and most likely not gainfully employed and the riots provided them a chance to be heard and perhaps to be taken "seriously", for the first time in their lives (Suransky et al., 2009; Kalinge-Nyago, 2011a; 2011b). The growing group of unemployed young men is an urban underclass that is prone to manipulation for political ends (Suransky et al., 2009). The impoverished young Baganda strongly believed that their misery under Museveni and National Resistance Movement (NRM) government would only be cured through Mengo, Kabaka Mutebi and the physical resources of the kingdom including areas like Kayunga supposedly being sliced off by the NRM (Guweddeko, 2013).

Rioting youths and syndicates questioned and established rules of belonging and contested those territories that belonged to "no-one"; while city residents had to make continuous assessments of zones of safety and danger, and act accordingly. Rioters drew on available resources and ideologies to define urban spaces as "ours," making territorial claims to places, seeking to exclude others, as well as trying to impose conformity. Thus, the city was re-structured spatially and the rhetoric of belonging and behavior became heated. Available evidence suggests that the hotspots in the city were divided into two zones: that for the Baganda loyalists and their associates; and the zone for the outsiders. Reports of hatred of the non-baganda ("abagwira") increased and television footage during the riots indicated that Baganda youths meted attacks upon "abagwira" resident in the city; a concern that demonstrates the complex dynamics of urban struggles, identity and who has the legitimate right to Kampala City. The rioters attacked any presumed beneficiary of the NRM regime including the rich, regardless of whether they were fellow Baganda, assumed Banyankore or the foreigners enjoying the privileges of "inves- 
tors" and "ghost investors” (Guweddeko, 2013). Indeed in the confrontations with the abagwira, one was required to "okulanya"-a custom of reciting one's ancestral line on both parents sides; a well-entrenched and traditional way for a Muganda to introduce himself or herself including personal names, father, grandfather, lineage details and ancestral home (obutaka); village (ekyaalo) and county (ssaza) as a way of discovering any previously (un) known relations (Suransky et al., 2009).

Thirdly; the violence reflected an increasingly fraught struggle between the Buganda authorities and the Ugandan government. Thus, while the riots were partly a show of Buganda force, they were also borne out of fear of the secessionist desires of districts such as Kayunga, which would diminish the kingdom's influence and reduce its overall power if Federo was restored (Economist, 2009). It was also suspected that the central government has stirred up the controversy to undermine the unity of Buganda Kingdom, given that the move to support the Banyala against Buganda could be seen as another manifestation of the same divide-and-rule strategy that led to the restoration of Buganda and other kingdoms in the first place (Suransky et al., 2009). By the time the authorities regained control and the king agreed to postpone travel to Kayunga, the rioting had exposed a deep undercurrent of anger and frustration (Greste, 2009) further exposing the tension between state control and the ambitions of the traditional Buganda kingdom. Several Buganda kingdom sympathizers reminded other Baganda that the Kabaka and his subjects in Buganda were in captivity. Venomous remarks that received free, airplay on the radio waves included Buganda should secede from Uganda', "Abagwira baddeyo gyebaava” (non-Baganda should go back to where they came from)." Since we (Baganda) are under constant attack by the enemy, the messages emphasized: "it was time for every loyal Muganda to openly declare their full allegiance to the Kabaka and our other institutions. They declared that Buganda would remain strong... "Buganda tetisibwa tisibwa” (nobody scares Buganda), “Abaganda temwemalako ttaka nga muliguza abagwira' (Baganda, don’t finish all the land by selling it to non-Baganda).”

While the president reported that the rioting was not about failing to address the problems concerning Baganda accusing elements trying to use that monarchy to get political power and meddling in partisan politics to undermine the government, Baganda loyalists argued that they didn't want to take power from central government at all. All they wanted was the legal authority (territorial and social power) and self-government to run their own affairs in a federo system, just as it was in the post-colonial constitution (Greste, 2009). Broadly, the crisis involved Museveni and Mengo claiming to have created the other. Guweddeko (2013) reported that deep seated animosities and broken promises exist between Buganda and the NRM government over the 1981 NRM/A War Agreement. The acrimony between Buganda and the central Government stems from the failure of the NRM government to honor Buganda’s demands. These demands were part of an agreement that was reached between Buganda and the NRM as a prerequisite for Buganda's involvement in the 1981 National Resistance Army (NRA) bush war (Mugagga, 2012). Museveni claims he won the war "alone”, made no "agreement to restore monarchies” but rather philanthropically reinstated Buganda Kingdom, Kabaka Mutebi and the Mengo administration while Mengo counterclaims that Baganda received, hosted, united under NRM/A and brought Museveni to power (Guweddeko, 2013; Conroy-Krutz \& Logan, 2012). Economist (2009) puts it succinctly;

He came to power with the help of Baganda peasants that had suffered during the Amin and Obote regimes, and he shored up this support by granting the wish of traditionalists for the return of a monarchy to the Buganda kingdom in 1993.

\subsection{Walk to Work (W2W) and Territorial Expressions of Discontent}

The W2W protest movement in Uganda was born as an umbrella committee of interest groups whose principal demand was, as its name suggested, walk to work and live with the high cost of living. A day to day description of the first days of the W2W is given by Goodfellow (2011) and Kizito (2015) but within the prevailing hardships, W2W was an expression of people's frustrations with escalating fuel and food prices together with the reckless spending of public money by government, without any sign of regard or feelings for ordinary people when the majority of Ugandans were living in abject misery (Bagala, 2012a; Mugisha, 2011b; Twinoburyo, 2011a). The W2W protests were led by Activists for Change (A4C); a non-partisan pressure group that hoped to use nonviolent, peaceful action to hold the Uganda government accountable for its policies. As well as bridging class and status divides, the urban based A4C skillfully used its sympathizers including the media to mobilize support and, through its diversity and leadership, drew in followers with diverse tribal, linguistic and regional identities. Clancy (2014) puts it that the A4C provides for; 
Citizens as formative agents, in the sense of providing their consent for the establishment of political arrangements and thereby bestowing legitimacy. They could also, or alternately, be considered as participative agents, in the sense of holding basic interests and rights that can be asserted as part of group deliberations.

Launched on $11^{\text {th }}$ April 2011 in Kampala City, after the February $18^{\text {th }}$, 2011 Presidential and Parliamentary Elections, the W2W protests were meant to highlight the deepening economic crisis in the country and how it impacted on ordinary working class Ugandans. Sejusa who is quoted by Lubwama (2016) questions the ideological depth of the W2W campaign and whether it could manage constructively the rather complex dynamics of moving a system from democratic centralism to liberal democracy without disrupting the social and political cohesion of the state. That notwithstanding, the campaign was designed to harness popular discontent when inflation had weakened to single digit figures following the global downturn, after averaging $12.5 \%$ during 2008-9, but had climbed steadily in the past six months-driven by rising food and fuel prices, and a weakening Ugandan shilling. In addition, government spending rose ahead of the polls-in line with January's supplementary budget of Uganda Shillings 600 billion-exacerbating these pressures (Izama \& Wilkerson, 2011; Mbazira, 2013). When a government has been in power for 30 uninterrupted years, it becomes inevitable that people will start asking questions about service delivery, accountability and crime and so on and ultimately will start demanding for change of some sort (Lubwama, 2016). The mission of A4C was to engage in non-violent action to foster peaceful change in the management of public affairs (Aljazeera, 2011 and Human Rights Watch, 2012) and to compel leaders at all levels to exercise sensitivity and compassion in the allocation of scarce and hard-earned resources. The key pillar on which A4C wished to anchor the values of the country was that all people had the national obligation at all times as Ugandans to hold leaders accountable.

By May 2011, not only had the W2W campaign continued, it had actually become the longest-running civil disobedience campaign since independence in 1962 (Kalyegira, 2011b). No matter how small the numbers involved in the W2W and other protests, there is no denying their sheer intellectual brilliance. That brilliance was in their simplicity, in their ability to confer on the simplest of human activities, walking, and a major political significance: the capacity to say no (Mamdani, 2011). It reflected the everyday experiences and struggles of a socially diverse and heterogeneous urban population. A4C called on middle class Ugandans to park their cars and join the W2W in order to bond with and show solidarity with the increasing number of people who had joined the ranks of hundreds of thousands of poor Ugandans especially the poor casual laborers, jobless, and the urban underclass that walk to work every day (Ddembe, 2011). The protests focused on economic issues, but carried a strong political component in that they were organized by members of the opposition parties and mostly split across government/opposition lines (Helle \& Rakner, 2014). Mugisha (2011c) articulates this well;

We know that those who are afraid of demonstrations of compassion and empathy with our fellow human beings are those who have reason to fear. They are the ones with the power to provide solutions but they have neglected to use that power. Instead they will spend a quarter of our national budget on fighter jets to protect themselves from imagined enemies, even as our children go to sleep hungry. We shall measure our worth as a people and as individuals by seeing how many cared to walk in empathy and compassion with those in need. We shall know our determination and courage to face those who would besiege our city to keep us silent in the face of suffering. Our courage will come not from our individual determination but from our collective resolve to face our fears and conquer them.

The symbolic and practical meaning of the A4C mobilization of city residents is very important to be emphasized here. The political opposition keen to show they were concerned about people's discontent-heeded the call to take part. Besigye, who, then was the head of the Forum for Democratic Change, announced that he and other opposition leaders would walk to work as a response to the call by A4C and that they had the right to do so (Aljazeera, 2011). Having tapped state resources so freely to guarantee election wins for Museveni and the NRM, the government had been caught flat-footed, without enough money on hand to augment national gasoline reserves or take other steps to ameliorate the public's distress-a distress that citizens all over Uganda could clearly trace to Museveni. It was a field day for Besigye and the opposition, and a massive embarrassment for the regime (Izama \& Wilkerson, 2011). Two other presidential contenders-DP leader Norbert Mao and Uganda People's Congress (UPC) leader Olara Otunnu-were also highly visible. It was also supported by other opposition groups, and by a number of civil society organizations (including senior figures within the Church of Uganda. 
The group promised to respect laws by walking to their place of employment; walking together because it was their constitutional right to associate with those they pleased as long as they did not jeopardize the rights and freedoms of others. This was consistent with what the Shadow Attorney General lucidly indicated;

Nobody is going to intimidate us. What the government needs to do is to address the problems facing our economy and stop the blame game. There was nobody preparing Ugandans for an uprising, but if [current] conditions prevail the people would stand up. It was up to the government to make sure that such conditions didn't prevail. Those people in government must address the problems in the country, ensure that there is democracy, stop mismanagement of public funds and promote good governance ${ }^{4}$.

The A4C on several occasions invoked the rights to free assembly and peaceful demonstration which are guaranteed under article 20 of Universal Declaration of Human Rights (UDHR) and Article 19 of the Civil political Rights Convention (ICCPR) to which Uganda is a signatory. The same right is recognized under Article 29(1) of the Uganda constitution which provides that every person shall have the right to (d) freedom to assemble and to demonstrate together with others peacefully and unarmed and to petition. This realization by Ugandans that they could take on the political establishment by simply walking to work defined, to some extent, how change could be achieved without waiting for the usually corrupt elective process to choose what they want (Masiga, 2012).

As a struggle which had begun as a battle over social justice, W2W protests evolved a strong spatial strategy with an elaborate struggle for urban space opposing the sitting government. When freedom of expression was met with suppression and oppression, then opposition became the A4C's position (Mukama, 2016). As images of police torture were broadcast on television stations, and were posted on the internet, they triggered riots in various locations around Kampala. The city is a restive places where criminal violence is alarmingly common in ordinary times, with political violence ready to flare as well should a precipitating event (such as a fuel-price spike) be added to the already-volatile mix (Izama \& Wilkerson, 2011). The earliest incidents were reported from various central locations, including the densely populated areas around Kisekka Market, the Old Taxi Park and Lugogo Stadium. However, they soon spread to various outlying locations as well, including the areas around the FDC headquarters in Najjanankumbi, and various sites along the Entebbe road (the largest being at Kajjansi, which is about $20 \mathrm{~km}$ south of Kampala). Later, they also spread to Makerere University, as well as to various other urban centres around the country (including Masaka, Mbale and Mbarara). At each of these locations, scores of mostly young men set tires and cars alight, and fought running battles with police and the army. The protest walks always started in Kasangati, but ended up anywhere en-route to Kampala with ugly though somewhat glorious run-ins with the militarized police (Musaala, 2016). The whole intention was to spatially articulate W2W demands by occupying city streets as the (then) Shadow Minister (then) for Internal Affairs indicated;

When those in government disagreed with those who were the government of the time, they chose to go to the bush [in 1980], our option is the streets ${ }^{5}$.

The suburbanization of the city gave the W2W another distinct spatial character. There was a marked decentralization of elements in A4C leading the W2W. While Kampala City remains functionally linked, A4C activities became increasingly fragmented into a complex mosaic of walkers, who practiced what Jansen (2001) described as "inserting” their bodies into non-accidental urban locations. Firstly, the protesters explicitly distinguished themselves from "villagers" (Jansen 2001), who for them epitomized obedience, political apathy and anti-citizenship. For as long as their actions could last, the protesters not only resisted arrest but were interested in gradually conquering new urban space from government authorities and undermining the capacity of the state to exercise surveillance. Furthermore, the protesters were interested in the most symbolic locations and spaces in the heart of Kampala City; preferably Constitutional Square, in what Jansen (2001) described as a strategy for "re-territorializing the city". Through filling the urban space with walkers, sympathizers and noise, long marches, and traffic obstructions, the W2W protesters re-shaped the city; through minor and major inconveniences that redefined the nature of the urban space.

\footnotetext{
${ }^{4}$ Mugerwa \& Naturinda (2011).

${ }^{5}$ Mugerwa \& Naturinda (2011).
} 


\section{Surveillance Actions and (De) Construction of Citizenship}

Six related areas of surveillance and response could be discerned including 1) urban securitization, arrest and detention of protesters; 2) (de) constructing protests and/as terrorism and treason; 3) urban space regulation and security zoning; 4) legal regulation of protests; 5) crackdown and censorship of the media; and 6) denial of the economic situation in the country. Although some of these actions were national in character, a large part of their deployment and visibility is in Kampala City.

\subsection{Urban Securitization, Arrest and Detention of Protesters}

Several security mechanisms of surveillance; watching and intelligence gathering in the city are part of what this paper calls the NRM security machine. The surveillance and securitization of demonstrations has become increasingly prominent. Citizen struggles have been grafted onto a pre-existing security infrastructure, which has evolved over many years in response to the threat of Baganda federalism and other forms of protest. The $\mathrm{Bu}-$ ganda riots set the real ground for expression of disagreement with government and extreme reaction from the authorities, use of live ammunition against unarmed civilians. The memory of Tahrir Square fed opposition hopes, inspired and fueled government fears (Baker, 2015; Helle \& Rakner, 2014; Mbazira, 2013). For many in the opposition, Egypt had come to signify the Promised Land and for those in government, Egypt spelt a fundamental challenge to power, one that had to be resisted, whatever the cost (Mamdani, 2011). From the beginning, the main story of W2W was the security forces' markedly draconian response to the protests. A detailed description of police reaction is given in International Crisis Group (2012), Kakuba (2015), Kjaer \& Katusiimeh (2012) but Odoobo-Bichachi (2012a) writes that the way the police had been programmed to react is that no political rallies would be allowed except with their permission.

The heavy-handed response bespoke a surprising lack of confidence for a government that had just secured a resounding re-election victory in 2011 (Conroy-Krutz \& Logan, 2012). Directly following his re-election for President in February 2011, Museveni firmly stated that he would not allow any protesting of any sort to occur in Uganda, as he did not want Uganda to become like other African countries. He forewarned political opponents and civilians alike that the harshest, firmest punishments would ensue for any such protesters (Feinstein, 2011). The psyche of the police was to handle protesters as enemies and it seems it would take time and experience for the Ugandan police to realize that their job wasn't to defend the regime against the people. The police would have running battles with protesters and the most egregious conduct of the police was in no uncertain terms, pointed at arresting and subsequent imprisonment of demonstrators. For civilians, supporters and skeptics alike, the sight of military resources deployed to maintain civil order in the streets, had come to blur the line between civil police and military forces as those in power insisted on treating even the simplest of civil protest as if it were an armed rebellion (Mamdani, 2011).

Following the failure to anticipate and interpret the protests, the military police reacted to the mostly peaceful demonstrations with extreme and vicious violence, using pepper spray, plastic bullets, tear gas, and firing grenades indiscriminately at fleeing protesters and bystanders, injuring many (Baker, 2015; Izama \& Wilkerson, 2011). Consequently, the protests escalated; becoming protests against the police's brutality, the right to demonstrate peacefully, the impunity and privilege of politicians, state's neglect of the peoples' needs and political corruption. In fact, Museveni knew that without controlling Kampala, his hold onto power was in balance and for Baker (2015) and Ssemuju (2012), a city that had consistently voted against him; one of the fronts to control it was security. Rather than increasing a sense of security within newly built and regenerated places, the new focus of police policy encourages the formation of new governmentalities of insecurity and fear.

The details of persons arrested are appropriately captured by Lubwama (2012) but by and large, arrestees were charged with serious offenses including assault, incitement to violence, concealment of treason and treason (Helle, et al, 2011; Mbazira, 2013; Vasher, 2011). In many cases, demonstrators using the public streets were barricaded in, severely restricted in their movements, kept away from the further movements or walking, and scores of youths who participated in the 2009 riots were put in prison for a period of over two years without trial (John Paul II Justice and Peace Centre, 2013) and many on charges thrown out subsequently by the courts for lack of prosecution evidence (Izama \& Wilkerson, 2011; Lubwama, 2012). The threat of detention without trial hanged heavy over the heads of the leaders of the protest movements and specific activists were targeted for the harshest measures so that others, it was expected would be frightened into silence. It was believed that the brutal crackdown would forever stop the protests and shock Ugandans back into their natural state of political detach- 
ment. In fact, NRM and its predecessors have always been principled forces battling opportunists (Museveni, 2011). Emorut \& Magara (2012), Khisa (2016a) and Njoroge (2012) report that the Prime Minister and President promised that no one could disturb the "peace” of the country. They would crush arrestees and wipe out the political opposition to remind Ugandans that they had defeated armed gangs and despotic regimes in the past, and winning wars was the greatest achievement of the president in his curriculum vitae as a leader (Ampurire, 2016; Emorut \& Magara, 2012; Guweddeko, 2013; Khisa, 2016a, Njoroge, 2012; Tumushabe \& Rumanzi, 2016) and the remaining problem was dangerous liars, lawless civilians, lumpens and hooligans (Bisiika, 2016).

Lawful assemblies were prohibited and the common excuse was that they destabilized the state, disrupted business, flows of production and well as the flow of goods and services in the City Centre. Makara, (2010) provides several grounds around which to reject this official or respected version of events considering that proNRM government assemblies were never dispersed. But images of children choking on tear gas, one brutally slain, and a man in bandages thrown behind bars just for walking to work were proving more powerful than the threat from the barrel of a gun (Gatsoiunis, n.d. In: Murumba, 2011).

The climax of the W2W protests was the violent and shameful arrest of FDC President Kizza Besigye. Led by a one Senior Police Officer Gilbert Bwana Arinaitwe with the help of a motley gang of security operatives, Besigye's vehicle was intercepted at Mulago roundabout as he attempted to drive to town (Ddungu, 2011). Using the butt of his pistol, Arinaitwe broke into Besigye's vehicle before incessantly dousing the FDC leader with pepper spray (Ddungu, 2011; Mutaizibwa, 2012; Red Pepper, 2016), temporarily blinding him (Acen, 2011). Like a rehearsed Hollywood blockbuster scene, video footage captured a hooded man using a hammer to break the window of Besigye's Land Cruiser vehicle. With remarkable ease, Arinaitwe later dragged Besigye out of the vehicle before bundling him on a patrol pickup (Ddungu, 2011; Red Pepper, 2016). While the images of the attack were so grim and caused a public outcry, Arinaitwe was cleared of any wrong doing (Insider, 2014; Sunrise, 2015; Wasswa, 2015) and later promoted and redeployed to the Directorate of Crime Intelligence in the Uganda Police Force (Kato, 2016; Red Pepper, 2016).

For a man whose political star and charisma was declining, these arrests gave him a second chance (Batanda, 2011). This was manifested in the crowd present to welcome him from Nairobi and the largest demonstration was witnessed on May 12, 2011 on Besigye's return from Nairobi on a day-long journey from Entebbe airport that overshadowed President Yoweri Museveni's inauguration/swearing in ceremony on the same day. To the common man feeling disenfranchised, associating with him with a message of social protest represented their suffering (Batanda, 2011). Attempts were further made by the $9^{\text {th }}$ Parliament to ensure the Constitution was amended to deny bail to among others, suspected rioters and "economic saboteurs" until they had spent six months on remand (Naturinda, 2011; Butagira, 2012b).

With the death of Police Constable Ariong during one of the demonstrations, a new platform to intensify repression of the A4C activists intensified. Police guidelines and surveillance approaches increasingly sought a spatial approach to control and regulation of the presence and absence of particular types of citizens in specific places at particular times. The geographical spaces including personal residences that A4C leaders relied on to organize were not haphazard or neutral locales in the Kampala urban landscape but they became sites of police deployment and targets of plain clothed security operatives to prevent the A4C leaders from leaving their homes. This interception of leaders in their homes; commonly referred as preventive arrest (home blockade and detention) was a common practice to deliberately frustrate the A4C. This preventive arrest was particularly acute and more pronounced with leaders of the opposition whose residences were frequently cordoned off by military and police officers when they attempted to walk to work. Preventive arrest' is a law which the British colonialists used against Uganda several decades ago to conveniently leave protesters under house arrest until the police was confident that leaders would not engage in protests (Mugisha, 2011b).

The massive recruitment and training of mercenaries by government to crack down on dissent was also proceeding apace. The security outfit that the government created in response to the W2W protests became so large, so unwieldy and so secretive that no one knew how much money it cost, how many people it employed, how many surveillance programs existed within it or exactly how many agencies did the same work. In sum, the military doesn't consist of one army, but of the Uganda Peoples Defence Forces and an increasing number of security organizations (Kjaer \& Katusiimeh, 2012). A quick stroll in Kampala City makes clear the Uganda security apparatus has adopted a more militarized language. The government has deployed security forces on almost every corner in every neighborhood in the city, like never before (Kagumire, 2011). Butagira (2012a) questions whether the battery of security outfits, referred to elsewhere as terror squads clad in police uniform, whose 
members are mostly unknown to the public or even to one another are the new faces of terror across the city. Their manners are covert, if not unconventional or outright wayward. In fact, they dress shabbily to disguise their identity and always cover their eyes with dark glasses. For civilians, supporters and skeptics alike, the sight of armed police and military personnel (Figure 2) as well as fierce armored vehicles roaming the streets, deployed to maintain civil order on the streets, has come to blur the line between civil police and military forces as those in power insist on treating even the simplest of civil protest as if it were an armed rebellion (Mamdani, 2011).

Omach (2010), Vasher (2011) and Titeca \& Onyango (2012) explore the proliferation of vigilantes and plain cloth militias in Uganda's politics but a stark observation is that a number of militias have sprung up to intimidate and coerce social identities into following government demands. Many Ugandans are still trying to get to the roots of two specific, massive unregulated, semi para-military vigilante groups of informal commandos/ goons called the Kiboko (stick) Squad and now Crime Preventers that often spring up on the streets in big numbers with long menacing sticks to clobber anybody trying to peacefully demonstrate. These plain clothed personnel armed with clubs, batons and canes have unleashed terror and beaten up people indiscriminately while the police standby and look on (Helle et al, 2011; Kigambo, 2011; Makara, 2010; Mulumba, 2011; WaMucoori, 2010).

Although the Uganda Police Force refers to crime preventers as an extension of the historical Nyumba Kumi (Ten Houses) and politically neutral community policing arrangement, and not in any way a militia force; their recent large scale recruitment, hasty training and political sensitization, outside a clear legal framework cannot escape the scrutiny and suspicion that they will act in favor of the ruling party, the NRM (Titeca \& Onyango, 2012; Observer, 2016; Ssekira, 2016) and enjoy its tacit official support (Omach, 2010). The political opposition believed strongly that the government was fully behind these militia groups whose main duty is to disrupt political assembly and deny mobilization by the opposition political organs. Their presence was broadly perceived as adding to an intimidating pre-electoral atmosphere and strong militarization in the run-up to the elections (Titeca \& Onyango, 2012; Insider, 2016). As the country prepares for the 2016 Presidential elections, the political opposition has suggested that government was training crime preventers as a planned scheme to rig elections and intimidate people to vote the incumbent President Yoweri Museveni as well as beat people who were not supporting the National Resistance Movement and its candidates (Titeca \& Onyango, 2012; Tugume, 2016).

\section{2. (De) Constructing Protests as/and Terrorism and Treason}

The government has criminalized popular protests and rallies by opposition activists in a bid to silence all dissent and opposition to government's policies and practices (Red Pepper, 2012). Just like the 1945 and 1949 reactions by the colonial government, there grew an ill-founded conventional wisdom which held that the causes of the disturbances were essentially political: that their origins and course could be understood only by reference

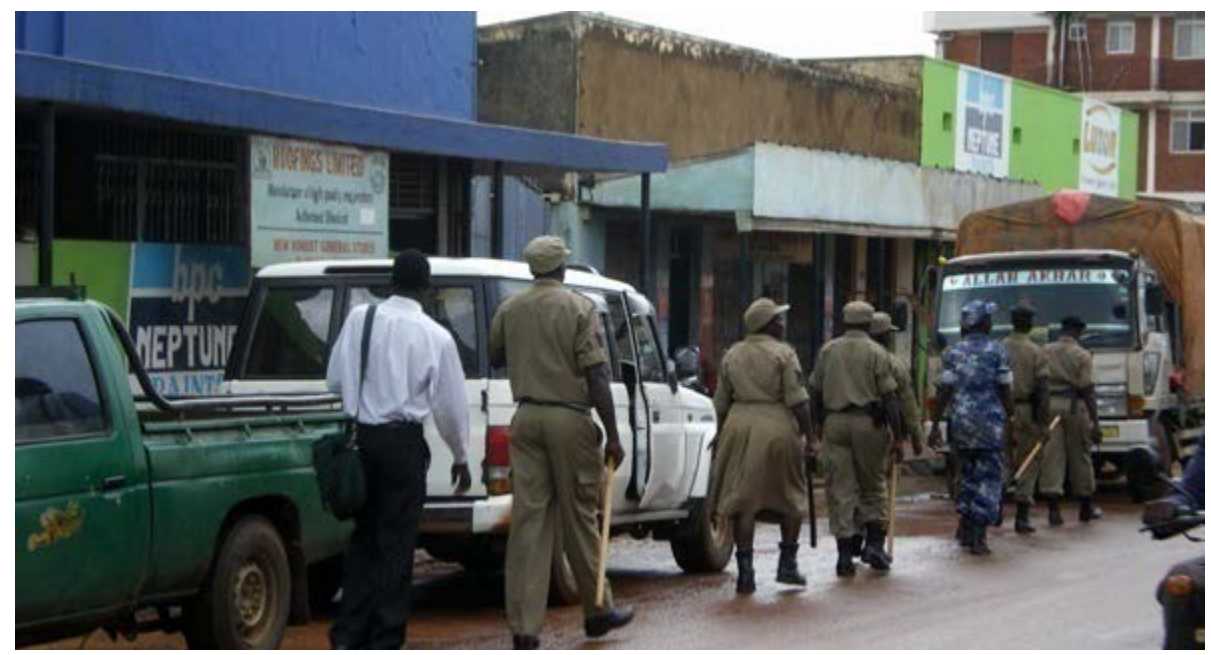

Figure 2. Human forms of intelligence aimed at looking out for possible signs of trouble and averting them. 
to the factional ambitions of a limited number of politicians (Thompson, 1992). The W2W protests were not seen in the lenses of food, fuel prices and general economic well-being of larger sections of Ugandan society. By denying them official recognition, protesters remained invisible in policy and their visibility in the urban environment remained at the status of lunatics. Protesters have been linked to terrorist groups that are bent upon wreaking a legitimate government and posing a concomitant challenge to state sovereignty. In fact, immediately, after the first protest were dispersed, the police indicated that the members of opposition parties were trying to use demonstrators as part of a wider ploy and political move that was psychologically preparing the public for an armed insurrection to overthrow a duly elected and legitimate government (Kagumire, 2011).

The IGP would issue terror alerts frequently to justify the continued presence of armed men in the city and of course every road roundabout and other important road junctions have what is now termed as a permanent military barracks or security cordon. Accusations by the IGP in the media indicated that A4C was spreading sectarian propaganda and training youths in terror tactics and police had information that there were training youths in Afghanistan by the Taliban and Al Qaeda and, some of whom had already infiltrated into the country (Athumani, 2011). The IGP added that other youths in Kenya were in the process of being smuggled into the country (Kampala Dispatch, 2011) although these allegations were ridiculed by the public and soon lost traction (Mugisha, 2011b).

It was further claimed that the opposition was portraying the government as illegitimate, claiming the NRM rigged the February $18^{\text {th }}, 2011$ general elections, and as such was opportunistically pressing for power-sharing (Mugerwa \& Naturinda, 2011). Mamdani (2012) reminds us that once in power, armed guerrillas have tended to be distrustful of independent popular activity, indeed of anyone who claims to have a different understanding of what the nation needs. That accusation seemed to gain credence from the utterances made by Besigye on his campaign trail in the run-up to the February $18^{\text {th }}, 2011$ presidential elections that he lost to Museveni. He indicated that he would not go to court as on previous occasions but use other means to fight an illegitimate government. The police were vindicated when according to Twinoburyo, (2011b), Democratic Party President Norbert Mao, speaking on behalf of four of his counterparts-Kizza Besigye (FDC), Olara Otunnu (UPC), Asuman Basalirwa (JEEMA) and Mabikke (SDP), said;

"We have concluded collectively that this is a broad struggle-whether it is teachers, boda bodas, taxi drivers, traders, political parties, students and lecturers-we are all together in this struggle," and that "a change of government is a clear goal that we are pursuing”.

This was consistent with what other leaders of the FDC indicated in their public rallies. Kitaka Kaaya (2012), for example, captured the sentiments of the Head of the FDC Women League;

I was jailed for two months at Luzira because Museveni claimed that I was plotting to remove him from State House. I want to clearly state it here that my biggest programme is that of removing Museveni and his thieving regime from power! I want to assure you that I no longer sleep; my daily programme is to overthrow President Museveni! This is provided for in the constitution, and I will not tire until we have achieved it.

\subsection{Urban Space Use Regulation and Security Zoning}

The W2W protests practiced those identifiable patterns of citizenship and the consequence of this practice was the profound alteration of the urban space. W2W protests emerged as instrumental in city residents' confrontation with the regime; it materialized to remind urban dwellers that urban public spaces were political arenas as much as they were pavement and asphalt. The use of military hardware to control city spaces and transport corridors, and issues regarding policing of the city in what is commonly referred to as unprecedented Ugandan peacetimes have dominated media reports. A number of critics describe how a hyper-securitization or militarization of the urban environment tends to filter users into oppositional categories, thus limiting the accessibility of spaces to only those deemed desirable or appropriate (Mitchell, 2003; Németh, 2010). The W2W protesters were dismissed because they encroached on public space; the streets and also encroached on other public spaces and business areas in the city as the government would claim. The police and other security forces intensified spatial regulation of social and economic behavior by invoking several edicts against the use of "popular spaces"; the areas in which the city population come together. Even before the terror attacks, owners and managers of highprofile public and private buildings begun to militarize spaces by outfitting surrounding streets and sidewalks 
with rotating surveillance cameras, metal fences and concrete bollards.

As long as W2W protesters were perceived as idle and disorderly on public space and the city in general, they were easily and sporadically eradicated from city spaces. In sum, there was a shift from general city space planning to spatially targeted and place-focused restrictions in the use of urban space in the city. Targeting interventions especially police blockades to geographically circumscribed areas further away from the Central Business District activities was presented as a path to remedy further protests and reduce their potential destructive effect. A quantifiable indicator on the frequency of public space closures, amount and intensity of physical space declared and lost for security zones/landscapes was beyond the scope of this paper, but a significant amount of city physical space has now been closed off from the public for security purposes.

Prior to the protests, regulation of use of urban space was purely a KCCA function and was administered through city physical planning guidelines. Mounting political pressure on KCCA and the accompanying protests in the city have resulted in a series of ordinances and Acts which have transferred responsibility for use of space to the Uganda Police Force. Several public spaces across the city have now become, what Nemeth (2009) refers to as closed or limited use anti-terror security zones with their related behavior and access controls. Five years after the protests, significant parts of the Kampala City Central Business District remain largely sealed off as "security zones." Some of these are illustrated in Figure 3 and Figure 4 but the most important space is Constitutional Square. It has completely been sealed off from public access and it is now dotted with gun wielding persons and armored vehicles stationed preparing for any potential threat. KCCA has argued that the use of Constitutional Square and nearby grounds was regulated by KCCA but the Uganda Police Force and several security/military outfits being in-charge of law and order were actually in-charge of the grounds.

The post-W2W period and associated security responses currently challenge the "right to the city" by limiting access to several urban zones across the city. The army and police have maintained a security ring around Kampala, searching vehicles driving into and from the city. Security checks have been set up at Namanve, seven miles from Kampala and at Kanyanya about five miles from the capital on Gayaza Road (Tumwine \& Kato, 2016). There are currently very few things an individual or group can do in Kampala's urban public space, without incurring at least disapproving looks, but often also formal warnings and fines. This fits very appropriately in Lefebvrian dialectical nature of space. On one hand existing government policy doesn't recognize the rights of protesters, which forces them to be stopped from walking. On the other hand because they "walk" this gives a greater incentive to the police and other security apparatus to remove them, because, as Knudsen (2007) argues, they don't fit the logic of the formal city and are easily dismissed as unworthy of citizenship rights. The right to perform a special activity in the city—such a Member of Parliament addressing his/her constituents-typically has to be frequently politically bought, and is therefore only accessible to those who can afford to buy it.

\subsection{Legal Regulation of Protests}

In response to rising protest the government has engaged in further legal maneuvering (Goodfellow, 2014) as part of a strategic repertoire to destabilize political opposition and demonstrators. The country has in recent times witnessed the passing of laws that undermine enjoyment of rights and an increase in proposals for legislation that would not only undermine the enjoyment of rights but also limit the citizen's role in governance and holding the state accountable. The country has also seen a push, seemingly out of nowhere, to enact new laws crippling newsgathering and criminalizing dissent. Bagala (2012b) reports that the final nail in the coffin of the A4C was laid on April 4 ${ }^{\text {th }}$, 2012, when the Attorney General invoked section 56 (2) (c) of the Penal Code Act and issued a statutory instrument that declared the A4C as "an unlawful society" rendering the group's activities illegal. Its membership was banned and if they tried to form any other group, it would also be deemed as unlawful'. The section outlaws any unlawful society and states that an unlawful society was one comprising of two or more persons whether known by name or not, if it was formed for the purposes of among others levying war or encouraging or assisting any person to levy war on government; killing or injuring or inciting to the killing or injuring of any person; destroying or injuring or inciting to the destruction or injuring of any property, subverting or promoting the subversion of the Government or of its officials and committing or inciting to acts of violence or intimidation (Ssenyonga \& Lule, 2012).

This pronouncement banned A4C and its coordinators from establishing or managing any society for at least two years. Under the same law, any person proved to be a member of A4C, would be jailed for seven years, 


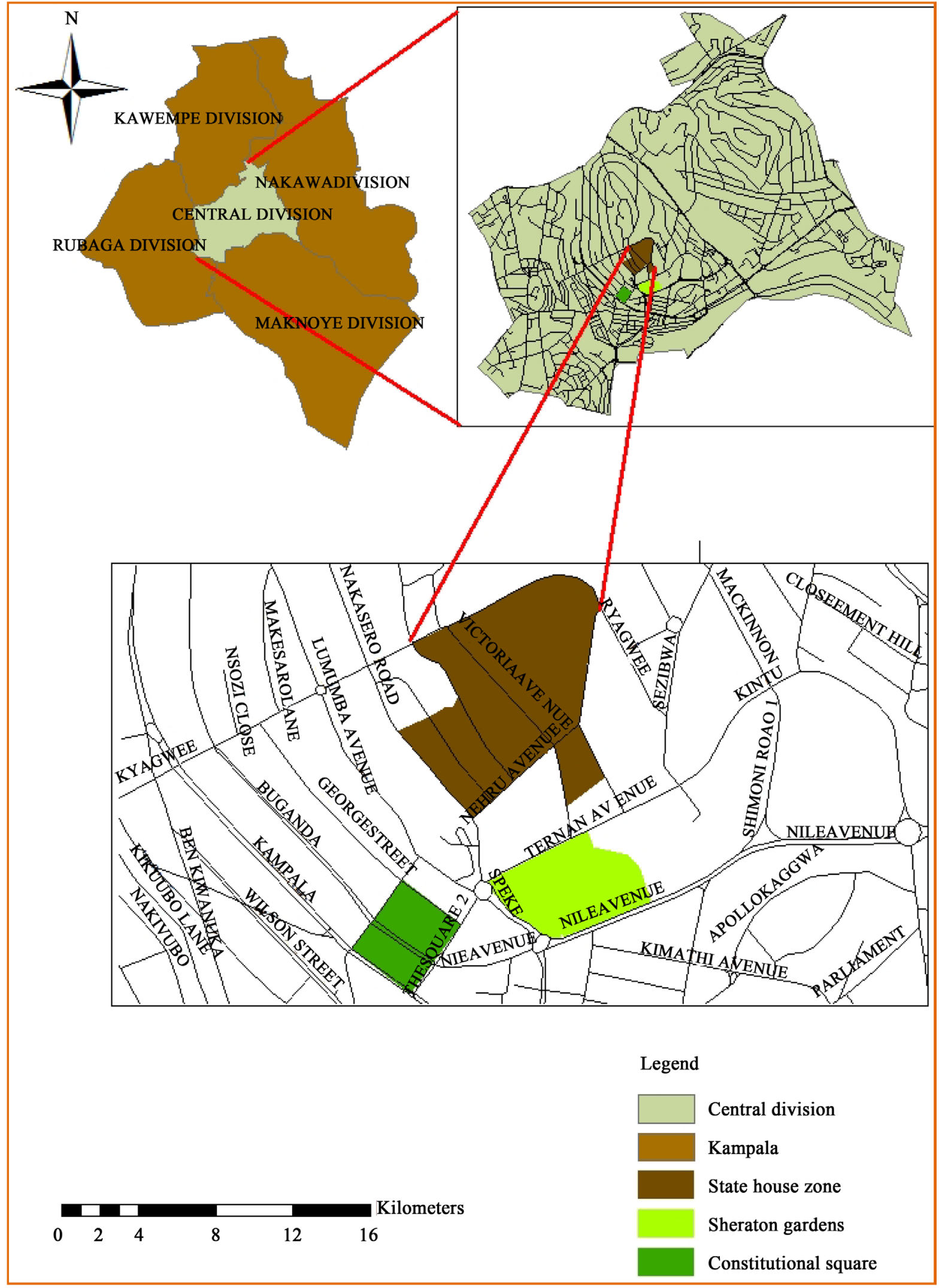

Figure 3. Closed public spaces in Kampala central business district. 


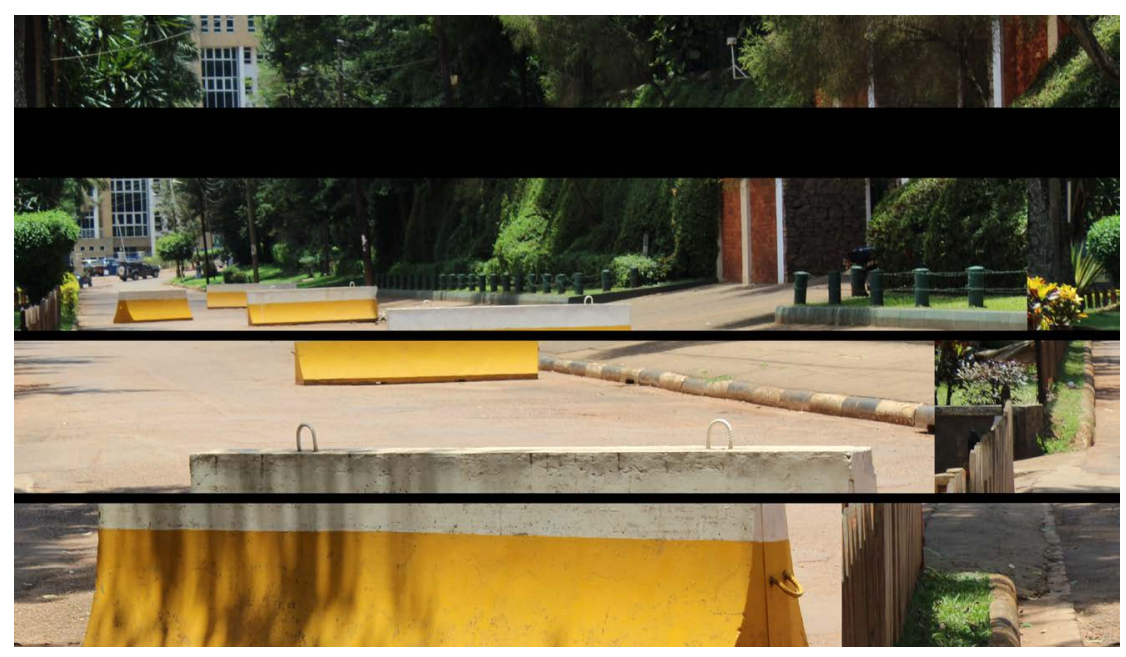

Figure 4. Examples of regulated public spaces in Kampala city-Kagera road.

while anyone who disseminated or published materials that supported the causes of A4C would be jailed for three years (Bagala, 2012c). By banning civil rights to protest, the President was hoping to drive the opposition in one direction in which he had comparative advantage and experience: violence. The effect of this directive and statutory instrument, illegal as it was, was to close peaceful avenues for Ugandans to express dissent and cause change in government policies or government itself. It also gave the police the wherewithal to come down hard on opposition demonstrators without worry about the law (Odoobo-Bichachi, 2012b).

The Public Order Management Act (POMA, 2013) was hurriedly passed to provide for: 1) the regulation of public meetings; 2) the duties and responsibilities of police, organizers and participants in relation to public meetings; [and] 3) measures for safeguarding public order. The law came into force in 2013 in the wake of the walk-to-work demonstrations and laden with the background of the Kayunga and "Save Mabira” riots (Baker, 2015; Mabala, 2015). Public order has been portrayed as people behaving in an orderly, thoughtful and respectful way in public spaces, but of course much depends on whose definition of good behavior, order and respect; and whose definition of illegitimate crowd violence (as opposed to legitimate revolt) (Baker, 2015). The underlying principle of managing public order is to regulate the exercise of the freedom to assemble and to demonstrate with others peacefully and unarmed (Republic of Uganda, 2013). The POMA grants the IGP and the Minister for Internal Affairs wide discretionary powers over the management of all public meetings (Republic of Uganda, 2013). Archival documents show that the police forces is required to have total control over the conduct of public gatherings, including the movements of demonstrators and their right to walk for meetings. The government contends that a stringent law was necessary to contain and control hooliganism that was disrupting public order under the pretext of enjoying constitutional freedoms. In the new law, public gatherings and processions must first give notification to the police, violation of which would constitute an offence of being unruly, riotous or engaging in economic sabotage (Odoobo-Bichachi, 2012c).

Proponents of the Act and several other Acts that were enacted during and after the riots argued that they were necessary to purge critical voices and protect public order in Uganda against a background of increased demonstrations that many times have resulted in destruction of property and inconvenience to those not taking part in the demonstrations. In a broad sense, the law can therefore be referred to as the anti-Besigye Act or the "ABA", as it was clearly designed to tighten the grip of the police and security forces in the wake of the W2W and For God and My Country (4GC) protests (Oloka Onyango, 2014).

\subsection{Crackdown and Censorship of the Media}

Urban protests in Kampala have become commonplace, due in part to their frequency but due also to the high coverage by the media. The media has served as a vehicle not only for challenging government policies but also for debating government and public morality, and behavior in the streets (Howard, 2003). 2009 was referred to as the worst year in the history of the media since its liberalization in the early 1990s. The Uganda Communications Commission (UCC) and Uganda Broadcasting Council have come out to warn the media against any mes- 
sages that might be seen to promote ethnic prejudice, civil violence, and public insecurity. Following the Buganda riots and W2W protests, Museveni in the state owned New Vision Newspaper has frequently blamed and referred to journalists and several media houses including Al-Jazeera, BBC, NTV, and the Daily Monitor as irresponsible people and they would have to be treated as such for inciting the violence (Clarke, 2011).

By invoking media and penal laws such as the Press and Journalists Act (1995), Press and Journalists Amendment Act (2006), Access to Information Regulations (2007), Electronic Media Act (1996), Regulation of Interception of Communications Act (2007) and Uganda Penal Code Act, the Ugandan government has arrested and prosecuted journalists, restricted those who can lawfully work as journalists, and revoked broadcasting licenses without due process (Freedom House, 2012). The Press and Journalist Amendment Act 2006 also requires print media to be annually registered and licensed by government regulatory bodies. It empowered the Media Council to deny licenses based on its assessment of the newspaper's values and allows the council to revoke them at will as well as criminalizing the publication of information deemed prejudicial to national security, stability, unity or economic interests (Freedom House, 2011). Following the Buganda riots, government officials asked television stations to stop broadcasting live pictures of the violence (MRT, 2009; Vasher, 2011). In some instances, government forces forcibly removed video footage from television stations, confiscated journalists' cameras and videotapes, and deleted photographs of dead bodies. Some journalists were also beaten attempting to report on the unfolding events.

The Uganda Police has suspended or banned a number of radio stations or shows (Freedom House, 2012). The treatment meted out to journalists is well illustrated in Human Rights Watch (2010) and its subsequent bulletins, and in all cases Ugandan journalists have been physically assaulted, pepper sprayed, blocked from accessing news scenes, harassed, intimidated, tortured, arrested and detained by the police, government officials and NRM party members, and in some instances, government-inspired criminal charges and released without any charges preferred against them (Ssempala, 2016). The Uganda Police accuses the journalists of inciting violence, unethical conduct, refusal to obey lawful orders and being in places where there is no news (Ssempala, 2016). According to Museveni, the 2009 Buganda riots were caused by and were an extension of the abuses at himself and the NRM from certain FM radio stations and Baganda journalists (Guweddeko, 2013). Popular outdoor town hall-style radio talk shows/community round table discussions referred to as the People's Parliament-Ebimeeza were banned in September 2009 immediately after the Kabaka riots because they were dominated by the political opposition and human rights activists despite being few in numbers compared to NRM cadres (Semuwemba, 2009). While the ebimeeza's core intention was to create forums to enhance public participation in governance and in holding their leaders accountable, it was broadly argued that under the Minimum Broadcasting Standards' of the Electronic Media Act, broadcasters or video operators could not ably ensure that the programmes they aired did not promote violence, were not distorted and were in compliance with the existing law (East Africa's Journalists Association, 2011). Five privately owned radio stations, 88.8 and 89.2 CBS FM, Ssuubi FM, Radio Two (Akaboozi ku Bbiri) and Radio Sapientia were closed down for a full year by the Broadcasting Council, claiming they were inciting rioters and abusing the president (Conroy-Krutz \& Logan, 2012; Freedom House, 2012). The situation degenerated further following the establishment of the Media Offences Department within the Uganda Police Force, to strengthen the government's aggressive arm against the media (Freedom House, 2012).

The most recent attack on journalists occurred to WBS Television cameraman Andrew Lwanga who was filming the arrest of unemployed youth activists when Old Kampala Police DPC; Joram Mwesigye, ordered his arrested and instructed his men to clobber and flog him on the road side. The journalist sustained injuries after being beaten and flogged on the tarmac while his camera was damaged as the police kicked him from all sides (Walukuka, 2015). Journalists have been threatened with phone calls and text messages, while others have been trailed by security agents especially those that had reported critically about the government, presented opposing political views, or exposed state wrongdoing (European Parliament, 2010; Gyezaho, 2012a, 2012b; Kagumire, 2011; Okeowo, 2011).

The government does not supervise internet use closely, but it does pay attention to social media (Freedom House, 2012). As the W2W attracted increasing media coverage, government responded by banning live coverage of the protests and issued a directive to internet providers to block two popular social websites (Izama \& Wilkerson, 2011; Warigia \& Camp, 2013). The ban of live coverage came after television stations showed horrific images of the police force's high-handedness in arresting members of the political opposition (Warigia \& Camp, 2013). Footage of the police firing teargas canisters into homes, schools, and hospitals, was also shown. 
Security forces prevented journalists reporting from the scene and approaching some political opposition figures who had been arrested. The Uganda Communications Commission (UCC) first denied knowledge of Facebook and Twitter being blocked but subsequently on February 18, 2016 only two hours after the Presidential and Parliamentary polls had opened, social media sites such as Whats App, Twitter and Facebook were blocked due to a threat to public order and safety (Aine, 2016; Baker, 2015; Kizza, 2016; Mugabe, 2016); to stop attacks by extremist groups and stop the political opposition from announcing their own election results to the public (Aine, 2016). Quoting the president, Ndushabandi (2016) reports that switching off of Facebook and Twitter was just "endozo" (sample), adding that those persons using satellite phones could as well be taken off air. The shutting down of social media on February 18 was not the first time communication was being blocked on Election Day. A day after the February 23, 2006, general election, government ordered and jammed the website of Monitor newspaper as well as the signals of its sister radio station, 93.3 K-FM in Kampala. The reason given for closing the radio station was relaying election results live from the Namuwongo studio (Mugabe, 2016).

\subsection{Denial of the Prevailing Economic Situation across the Country}

To use Thompson's (1992) words; the origins of the riots, the state response to them and the official interpretation of what took place, all provided a clear evidence of the government's dwindling grasp of reality. While the facts were so clear on the economic situation in the country and how it affected the majority of the population especially the poor, there were those in government who continued to be in simple denial of the facts altogether. Others combined denial and rationalization and fell in the minimization state where they admitted the prevailing economic facts but denied their seriousness. Indeed, some NRM sympathizers were apparently surprised and shocked to receive frank and bitter criticism from fellow party supporters, human rights groups, churches, students, trade unions, and business groups accusing the government and its cronies of monopolizing power and raiding the national treasury. Yet, as Psychologist Sigmund Freud indicated, others were in a state of projection where they admitted both the facts and seriousness but denied responsibility.

In what his critics have called "sheer escapism" using "red herring fallacy" President Museveni has attacked the opposition, the media and environmentalists, branding them as "enemies of progress and the country's recovery" (Akaki, 2011; Clarke, 2011) and therefore responsible for the prevailing economic crisis. The media were the translators but also the amplifiers of events, weaving a single narrative out of isolated incidents for the general public (Body-Gendrot, 2011). Over the last 25 years, the government has perfected this tactic and like some of the prolific politicians in his kiln, the trick has frequently been to confuse and cloud an issue by bringing up irrelevant issues, so that the original point gets lost. At the end of it all, everybody gets distracted by arguing over the validity of the new issues he has raised (Mwenda, 2012). Other opposition critics were arrogantly labeled as petty conmen trying to rip off donors by staging political stunts and street hooliganism so as to account for the funds. For example in one of the blog postings, Mugisha (2011a) while appearing on a radio station in Kampala was reminded arrogantly by a rival NRM insider and Member of Parliament, Margaret Muhanga that they would let the A4C walk on Sunday because the shops were closed so they could not loot!

\section{Conclusion and Implications for Urban Policy}

Much as the protests have subsided, urban areas have become the new places of revolt and the three cases explored in this paper leave behind a number of policy implications. What came out strongly is that there is a dearth of urban policy ideals and practices in Kampala City that relate closely with protest movements in the city. Even when considered as emerging challenges for city authorities, there has not been any serious effort over the last ten years to mainstream security and protest concerns in urban policy in Kampala city. The examples of protests given in the paper have articulated mass grievance about a range of issues that revolve around the government's neglect of the people and their basic needs, as well as existing socioeconomic and political inequalities. The Save Mabira Forest campaign was an example of how sustained protests by civil society groups serve as a corrective of democratic deficits in decision-making processes pertaining to the commons and as a deterrent to profit-driven business schemes hatched in collusion with carefree or corrupt bureaucrats and politicians (Honig, 2014). People were angry at the lack of government provisioning and investment in the basic foundations of society and services they depended on daily-education, housing, health and transport. They were angry at escalating costs of living. They were angry at non-equitable salary raises. They were angry at rising inflation. All these came at a time when the government fronted an "emerging economy narrative" which would 
deliver the country to middle income status by 2017.

The spirit of the W2W, Buganda riots and Mabira protests is still alive and active in all parts of country. The paper was completed at a time when Uganda was entering the 2016 Presidential elections and similar sentiments of defiance, the potential for collective mobilization and militancy were re-echoed by the main presidential candidates. Shortly after 1986, Uganda embarked on what many people felt was the best chance for reversing the politics of the past and entering a new political era (Rubongoya, 2007; Besigye, 2011). There is no denying that there is no dearth of direct and indirect beneficiaries of Museveni's "eating" system, paid propagandists and unpaid apologists, official and unofficial spokespersons to belabor the point of the current government being the best thing to have happened to this country (Khisa, 2016b). They speak with the bravado and self-assuredness of men who knows their facts and they are the custodians of all the truth about the government, what is good and bad for Uganda. Like other regime functionaries and acolytes, they don't tire to tell the world that "they are in charge" (Khisa, 2016c).

A people's dream of freedom has become a nightmare of a hijacked state. While relative calm was restored after the protests, the country continues to grapple with several basic challenges. The famously announced 10point program for recovery that had been designed to end the suffering of the people of Uganda was abandoned before its implementation began (Kashambuzi, 2015). There is a lot of frustration about the continuing poverty and (youth) unemployment (Suransky et al., 2009) and with more than 80 percent of the youth population continuing cobble an existence through gambling and motorcycle taxi business, it is likely that he (Besigye) would have quite a following to ride along (Serunkuma, 2016). The protests highlighted that there was resentment within the Ugandan public and the opposition had the potential to mobilize (significant) segments of the Uganda population (Helle \& Rakner, 2014). To ignore, deny or underrate the economic circumstances that prevailed then was not only a distortion of the state of affairs across the country but also underscored the deliberate attempts to ignore reality in favor of a preconceived ideological position. The suppression of the disturbances and riots shouldn't lead government officials to conclude that all is well, peaceful and secure in the country. It is going to be pretty much difficult for the government to find a remedy against protests in the short term because the emotions that drive them are beyond the desire to simply get a better service but are embedded in the human longing for freedom. Unless, this is resolved, many more riots under prevailing circumstances will certainly emerge. Urban policy and security planning needs to strongly consider claims as genuine and should initiate and foster a discussion of a more inclusive and citizen-oriented form of security for urban areas across the country.

The euphoria of liberation across the country has given way to palpable anger at a government which superintends a state that had been merged with personalities. The Ten Point Program had been consolidated into just one, namely, L'Etat, c'estmoi (I am the state). He owns the money, the oil, and the army-the entire animal that was skinned with the blood of thousands (Muniini, 2016). It is sad that lives had to be lost just because the Ugandan Government felt it wise to restrict the movement of its citizens within their nation and chose to use extremely excessive force in stopping demonstrators who then turned violent as they saw their civil liberties being denied (Mivule, 2009). The riots shouldn't be narrowly interpreted as a class struggle between Buganda Kingdom, A4C, environmentalists and the central government. What is very important is that all actors and leaders focus on the most important aspects for Ugandan society such as delivering better services and reduce existing tensions in our society, which, if approached in a strategic and inclusive manner, can be resolved (Lubwama, 2016; Suransky et al., 2009). Many failures often result from the tendency of the people who are in charge, to keep their heads-down in denial of this fact (Lubwama, 2016). As the country enters the next phase of governance with the February, $18^{\text {th }} 2016$ Presidential elections, one of Uganda's sworn radical and queer feminist scholar, Nyanzi (2016), applies satirical perspectives to explain the current state of affairs in the country;

Country is being "raped". Being raped daily by a dominatrix lover who wooed you thirty years ago normalizes this violence. Simply because the lover liberated you from brutal ex-husbands, washed the pus oozing from your wounded body, bought you nice dresses and gave you a Banco bed to sleep in peace, does not erase the violence and lack of consent with which he rapes you these days. Your lover of thirty years ago became your sick rapist the day he paid our impotent elite a few glittering coins to tear presidential term limits out of the constitution. Where are the remnants of those coins, you traitors? We are stuck with a despot who does not see that the elastic in his pants and underwear got tired many years ago. The children are seeing his wrinkled manhood that violently pounds Mother Uganda, year after year after painful year. You are being raped, Uganda. 
The basis of security, peace and authority should not be measured by having a permanent military presence on the city streets. The use of live ammunition to disperse protests at an important Buganda cultural site illustrates the ready nature of the Museveni government to employ violence to repress civil rights. Peace that is maintained by force or through force or coerced through military might on the street is short lived. Employing force to curtail these civil rights undermines any citizen attempts to check runaway political power, since they lack the capabilities of violence necessary to check the military power of state (Vasher, 2011). As Walusimbi (2016) argues, the impunity calls for the police top brass and subordinates to review their rules of engagement especially in relation to the practice of journalists otherwise history will judge them harshly even though sometimes for the sake of expediency, in the African political experience, legacy is considered irrelevant and inconsequential by some political actors.

Most of the protest movements were spatially grounded and at the core of all protest movements, Kampala City was central to their world view. For the A4C and its W2W, the use of city streets, markets and public spaces, and refusing to leave when approached by police and other security operatives implicitly indicated that urban areas especially Kampala City was a place bound up with the identity of communities rather than a disposable product in a global market place. The A4C refused to treat the city center and other public spaces with indifference, in other words, it decided that the city center and walking to work were critical to its being, its identity, or its conception of its rights to assembly. As Taw and Hoffman (1995) recommend, the government must walk the fine line between overlooking or ignoring the development of protest movements on one hand, and overreacting with repressive legislation and brutal counterattacks on the other. There is a need for KCCA and Uganda Police to rethink the use of, control and regulation of public spaces for the benefits of the general public.

The very publicness that characterized the physical spaces of Kampala City is gradually being lost with the growth of privately owned public space. From privatized shopping malls and plazas to secured streets, opportunities for free expression are waning, especially since the imposition of security zones after the W2W protests in 2011. As part of its law and order imperative the Uganda Police has not partnered well with urban authorities especially KCCA and other law enforcement agencies to mainstream security and other intelligence security systems in urban areas. If the security landscape is to become a permanent of our urban areas, then there is a need for a new urban policy and planning approach that takes care of them.

\section{References}

Acen, C. (2011). Letter from Kampala: Besigye in Hospital after Brutal Police Beating. http://www.thelondoneveningpost.com/letter-from-kampala-besigye-in-hospital-after-brutal-police-beating/

Aine, K. (2016). UCC: We Shut down Social Media to Prevent Terrorism. http://www.chimpreports.com/ucc-we-shut-down-social-media-to-prevent-terrorism/

Akaki, T. (2011). Mabira Forest Giveaway: A Path to Degenerative Development. Bloomington, IN: iUniverse Inc.

Aljazeera (2011). Protests in Sub-Saharan Africa. http://www.aljazeera.com/indepth/features/2011/04/201141014942125983.html

Alvarez, S. E., Dagnino, E., \& Escobar, A. (Eds.). (1998). Cultures of Politics/Politics of Cultures: Revisioning Latin American Social Movements. Boulder: West view Press

Ampurire, P. (2016). Museveni Promises to Scrap “Idle and Disorderly” Law. http://www.chimpreports.com/museveni-promises-to-scrap-idle-and-disorderly-law/

Ansley, F. (2010). Constructing Citizenship without a license: The Struggle of Undocumented Immigrants in the USA for Livelihoods and Recognition. Studies in Social Justice, 4, 165-178.

Asiimwe, A. (2009). When Buganda Turned Violent. New African, 480, 42.

Athumani, H. (2011). Activists Threaten to Institute Private Prosecution of IGP. http://ugandaradionetwork.com/a/story.php?s=37220

Avuni, A. (2011). Living in Kampala Slum: A Socio-Economic Analysis in Ten Informal Settlements of Kampala. Kampala-Uganda, 2011, No. 3. Kampala: John Paul II Justice and Peace Centre.

Bagala, A. (2012a). Government Pays Irish PR firm Shs. 2bn to Clean Image Dented by Walk to Work. Saturday Monitor. http://www.monitor.co.ug/News/National/-/688334/1329522/-/b0pa8kz/-/index.html

Bagala, A. (2012b). Government Now Bans A4C. http://www.monitor.co.ug/News/National/-/688334/1379806/-/awmigaz/-/index.html

Bagala, A. (2012c). Civil Society Condemns A4C Ban. 
http://www.monitor.co.ug/News/National/-/688334/1381140/-/aw6oi6z/-/index.html

Baker, B. (2015). Unchanging Public Order Policing in Changing Times in East Africa. Journal of Modern African Studies, 53, 365-389. http://dx.doi.org/10.1017/s0022278x15000567

Barkan, J. D. (2011). Uganda: Assessing Risks to Stability. Washington DC: Centre for Strategic and International Studies.

Batanda, J. (2011). 2011: The Year of the Ugandan Protester. http://jackeebatanda.wordpress.com/2011/12/31/2011-the-year-of-the-ugandan-protester/\#more-317

Bender, J. (2014). These are the countries that have destabilized the most over the past 3 months. (Last accessed 21 January 2016) http://www.businessinsider.com/map-shows-the-highest-increase-in-civil-unrest-2014-10

Benyon, J., \& Solomos, J. (1988). The Simmering Cities: Urban Unrest during the Thatcher Years. Parliamentary Affairs, 41, 402-422.

Besigye, K. (2011). 25 Years of Broken Promises.

http://www.independent.co.ug/election-watch/3890-25-years-of-broken-promises

Bisiika, A. (2016). The Besigye Menace, lumpen Proletariat and Lumpen Militariat.

http://www.monitor.co.ug/OpEd/Commentary/The-Besigye-menace--lumpen-proletariat-and-lumpen-militariat/-/689364/3 103140/-/6ufaomz/-/index.html

Body-Gendrot, S. (2011). Disorder in World Cities: Comparing Britain and France. https://www.opendemocracy.net/ourkingdom/sophie-body-gendrot/disorder-in-world-cities-comparing-britain-and-france

Bratton, M., \& van de Walle, N. (1992). Popular Protest and Political Reform in Africa. Comparative Politics, $24,419-442$. http://dx.doi.org/10.2307/422153

Brenner, N. (2009). What Is Critical Urban Theory? City, 13, 198-207. http://dx.doi.org/10.1080/13604810902996466

Butagira, T. (2012a). Police Commandoes Are Bangi Smoker. Sunday Monitor, January 22, 2012 Pages 1-3. Kampala: Monitor Publications.

Butagira, T. (2012b). Security Chiefs Split on Crushing Demos.

http://www.monitor.co.ug/News/National/Security+chiefs+split+on+crushing+demos/-/688334/1402314/-/5yhaebz/-/inde $\underline{\text { x.html }}$

Calhoun, C. (1995). Rethinking Critical Theory. C. Calhoun, Critical Social Theory, 1-42.

Child, K. (2009). Civil society in Uganda: The Struggle to Save the Mabira Forest Reserve. Journal of Eastern African Studies, 3, 240-258. http://dx.doi.org/10.1080/17531050902972659

Clancy, P. (2014). Freshwater Politics in Canada. University of Toronto Press. Toronto.

Clarke, J. (2011). Journalists under Siege in Uganda. Mail and Guardian Online. http://mg.co.za/article/2011-05-27-journalists-under-siege-in-uganda

Conroy-Krutz, J., \& Logan, C. (2012). Museveni and the 2011 Ugandan Election: Did the Money Matter? The Journal of Modern African Studies, 50, 625-655. http://dx.doi.org/10.1017/S0022278X12000377

Davis, M. (1992). City of Quartz: Excavating the Future in Los Angeles. New York: Vintage Books

Ddembe, D. (2011). The Lunatics Are in Charge of the Asylum-Uganda. http://ugandaspeaks.wordpress.com/2011/04/30/the-lunatics-are-in-charge-of-the-asylum-uganda/

Ddungu, M. E. (2011). Besigye’s Tormentor “Hides” in Cop School. https://dungu.wordpress.com/category/human-rights-abuses/page/6/

Dear, M., \& Flusty, S. (1998). Postmodern Urbanism. Annals of the Association of American Geographers, 88, 50-72. http://dx.doi.org/10.1111/1467-8306.00084

East Africa’s Journalists Association (2011). EAJA Cautions against Stringent Broadcast Media Regulation. http://eaja.org/en/contents/eaja-cautions-against-stringent-broadcast-media-regulation

Economist (2009). Kingdom Come. http://www.economist.com/node/14442349

Emorut, F., \& Magara, D. (2012). Government Warns Walk to Work Protesters. http://www.newvision.co.ug/new_vision/news/1308025/govt-warns-walk-protesters

European Parliament (2010). Uganda: Journalists under Threat: End Intimidation of Rural Media and Amend Repressive Laws before 2011 Elections.

http://www.europarl.europa.eu/meetdocs/2009 2014/documents/droi/dv/201/201101/20110124 407hrwjournalist en.pdf

Feinstein, G. B. (2011). Social Unrest in Uganda. Gloria Baker Feinstein Blog.

http://gloriainafrica.blogspot.ug/2011/04/social-unrest-in-uganda.html

Freedom House (2012). Countries at Crossroads 2012: Uganda. https://freedomhouse.org/report/countries-crossroads/2012/uganda 
Golooba-Mutebi, F., \& Hickey, S. (2013). Investigating the Links between Political Settlements and Inclusive Development in Uganda: Towards a Research Agenda. ESID Working Paper No. 20. http://dx.doi.org/10.2139/ssrn.2386684

Goodfellow, T. (2010). The Bastard Child of Nobody? Anti-Planning and the Institutional Crisis in Contemporary Kampala. Crisis States Research Centre Working Paper Series No. 2. London School of Economics.

Goodfellow, T. (2011). The Institutionalization of "Noise" and "Silence" in Urban Politics: Case Studies from East Africa. Working Paper Number 188. QEH Working Paper Series-QEHWPS188. London: Department of International Development. London School of Economics and Political Science.

Goodfellow, T. (2014). Legal Maneuvers and Violence: Law Making, Protest and Semi-Authoritarianism in Uganda. Development and Change, 45, 753-776. http://dx.doi.org/10.1111/dech.12097

Greste, P. (2009). Royal Riots Expose Uganda Tensions. http://news.bbc.co.uk/2/hi/americas/8260130.stm

Guweddeko, F. (2013). Radio Free Buganda.

https://m.facebook.com/notes/radio-free-buganda/fred-guweddeko-gives-the-roots-of-the-tubuhaburwa-nrm-government-a nd-buganda-con/647856568576001/

Gyezaho, E. (2012a). Condemnation Grows over Police Shooting at Journalist. http://www.monitor.co.ug/News/National/-/688334/1314632/-/b1f9wez/-/index.htm

Gyezaho, E. (2012b). We're Back to the Dark Days, Says Tumwine. http://www.monitor.co.ug/News/National/-/688334/1382172/-/aw604az/-/index.html

Harvey, D. (2012). Rebel Cities: From the Right to the City to the Urban Revolution. Veso Books.

Helle, S. E., \& Rakner, L. (2014). Grabbing an Election: Abuse of State Resources in the 2011 Elections in Uganda. In T. Soreide and A. Williams (Eds.), Corruption, Grabbing and Development: Real World Challenges (pp. 161-171). Cheltenham and Northampton (MA): Edward Elgar Publishing.

Helle, S. E., Makara, S., \& Skage, I. A. (2011). When Elections Consolidate Power. The Futile Fight of the Ugandan Opposition in the 2011 Elections. CMI Brief, 10.

Holston, J. (1998). Spaces of Insurgent Citizenship. In L. Sandercock (Ed.), Making the Invisible Visible, A Multicultural Planning History (pp. 37-56). London: University of California Press.

Honig, P. (2014). Civil Society and Land Use Policy in Uganda: The Mabira Forest Case. Africa Spectrum, 2, 53-77.

Howard A. M. (2003). Cities in Africa, Past and Present: Contestation, Transformation, Discourse. Canadian Journal of African Studies/Revue Canadienne des Études Africaines, 37, 197-235. http://dx.doi.org/10.2307/4107238

Human Rights Watch (2010). A Media Minefield: Increasing Threats to Freedom of Expression in Uganda. New York. Human Rights Watch.

Human Rights Watch (2012). Uganda: Country Summary. New York. Human Rights Watch.

Independent (2010). 2009 Buganda Crisis. Independent Magazine (pp. 1-4). 22 December 2009, Kampala, Uganda.

Insider (2014). DPP: Arinaitwe Was Right to Brutally Arrest Besigye. http://www.theinsider.ug/dpp-arinaitwe-was-right-to-brutally-arrest-besigye/

Insider (2016). EU: Uganda EC Not Transparent, UCC Just Unreasonable. http://www.theinsider.ug/eu-uganda-ec-not-transparent-ucc-just-unreasonable/

International Crisis Group (2012). Uganda: No Resolution to Growing Tensions. Africa Report, No. 187.

Isin, E. F. (Ed.) (2000). Democracy, Citizenship and the Global City. London: Routledge.

Izama, A., \& Wilkerson, M. (2011). Uganda: Museveni’s Triumph and Weakness. Journal of Democracy, 22, 64-78. http://dx.doi.org/10.1353/jod.2011.0044

John Paul II Justice and Peace Centre (2013). The State and Cultural Institutions in Uganda: Buganda and Bunyoro Kingdoms. Kampala: John Paul II Justice and Peace Centre.

Kabeer, N. (2002). Citizenship, Affiliation and Exclusion: Perspectives from the South. IDS Bulletin, 33, 12-23. http://dx.doi.org/10.1111/j.1759-5436.2002.tb00021.x

Kagumire, R. (2011). Both Uganda’s Protesters and Its Government Draw Lessons from Egypt Revolution. Africa Monitor. http://www.csmonitor.com/World/Africa/Africa-Monitor/2011/0427/Both-Uganda-s-protesters-and-its-government-draw-l essons-from-Egypt-revolution

Kakuba, S. J. (2015). Political Violence in Plural Democracies: A Comparative Study of Uganda and KENYA. In S. S. Ercetin (Ed.), Chaos, Complexity and Leadership 2014. Berlin: Springer.

Kalinge-Nyago, O. (2011a). Why Uganda's Youth Seek Their Own New Political Direction. http://activists4change.blogspot.com/

Kalinge-Nyago, O. (2011b). Uganda Now Looks like Mobutu’s Zaire. http://activists4change.blogspot.com/ 
Kalyegira, T. (2011a). The problem in Uganda Is the Economy, Silly. Kampala Dispatch. http://dispatch.ug/its-the-economy-silly/3117/

Kalyegira, T. (2011b). A Hammer and a Gun-Analysis by Timothy Kalyegira. http://blogspirit.ug/node/23421?page=5

Kampala Dispatch (2011). Inspector General of Police accuses Activists for Change of Training Terrorists. Kampala Dispatch: Uganda's News Monthly.

http://dispatch.ug/inspector-general-of-police-accuses-activists-for-change-of-training-terrorists/2907/

Kashambuzi, E. (2015). Uganda: Gen. Museveni’s and NRM’s 30 Years of Failure and Why Opposition Must Boycott the Vote. http://www.blackstarnews.com/global-politics/africa/uganda-gen-musevenis-and-nrms-30-years-of-failure-and-why

Kato, J. (2016). Besigye Tormentor Gilbert Arinaitwe Redeployed. http://www.monitor.co.ug/News/National/Besigye-tormentor-Gilbert-Arinaitwe-redeployed/-/688334/3061648/-/c0dt7iz/-/ index.html

Khisa, M. (2016a). Museveni Is an Illegitimate President-Elect. http://observer.ug/viewpoint/42804-museveni-is-an-illegitimate-president-elect

Khisa, M. (2016b). Thinking about Post-Museveni Uganda. http://observer.ug/viewpoint/43036-thinking-about-post-museveni-uganda

Khisa, M. (2016c). Our Arrogant Rulers Need Salvation. http://observer.ug/viewpoint/43146-our-arrogant-rulers-need-salvation

Kibanja, G. M., Kajumba, M. M., \& Johnson, L. R. (2012). Ethno-Cultural Conflict in Uganda: Politics Based on Ethnic Divisions Inflame Tensions across the Country. In D. Landis, \& R. D. Albert (Eds.), Handbook of Ethnic Conflict: International Perspectives (pp. 403-435). Berlin: Springer Sciences and Business Media. http://dx.doi.org/10.1007/978-1-4614-0448-4_16

Kigambo, G. (2011). Kiboko Squad Investigation Reveals too Little. http://observer.ug/index.php?option=com_content\&task=view\&id=12444\&Itemid=59

Kitaka Kaaya, S. (2012). A4C Activists Rally Ankole to Overthrow Museveni This Year. The Observer Newspaper. http://www.observer.ug/index.php?option=com content\&view=article\&id=17501:a4c-activists-rally-ankole-to-overthrowmuseveni-this-year\&catid=34:news\&Itemid=114

Kizito, A. (2015). The Post-Independence Conflicts in Uganda: A Manifestation of the Classical Imperialistic Divide and Rule Policy of the British Colonial Administration in Uganda. Developing Country Studies, 5, 56-75.

Kizza, J. (2016). Social Media, Polls: Government Assures Public on Security. http://www.newvision.co.ug/new_vision/news/1417666/live-prime-minister-addresses-nation

Kjaer, A. M., \& Katusiimeh, M. (2012). Growing but Not Transforming: Fragmented Ruling Coalitions and Economic Developments in Uganda. DIIS Working Paper 2012:07. Copenhagen: Danish Institute for International Studies.

Knudsen, A.-M. S. (2007). The Right to the City: Spaces of Insurgent Citizenship among Pavement Dwellers in Mumbai, India. UCL Development Planning Unit Working paper No. 132.

Kock, de. P. (2011). Buckshot and Police Batons in Kampala. In: Institute for Security Studies (2011). The Price of Protest. Issue 13, 2011. Pretoria/Tshwane.

Lamarca, M. G. (2010). Institutionalizing Insurgent Claims. Towards “Good” Planning? Journal of Landscape Studies, 3, 77-86.

Lefebvre, H. (1991). The Production of Space. (D. Nicholson-Smith, Trans.). Cambridge, MA: Blackwell.

Lehman-Wilzig, S., \& Ungar, M. (1985). The Economic and Political Determinants of Public Protest Frequency and Magnitude: The Israeli Experience. International Review of Modern Sociology, 15, 63-80.

Lindemann, S. (2010). Exclusionary Elite Bargains and Civil War Onset: The Case of Uganda. Crisis States Working Paper (Series 2), 76.

Lister, R. (1997). Citizenship: Feminist Perspectives. New York: New York University Press. http://dx.doi.org/10.1007/978-1-349-26209-0

Lofland, L. H. (2000). Urbanity, Tolerance and Public Space: The Creation of Cosmopolitans. In L. Deben, W. Heinemeijer, \& D. van der Vaart (Eds.), Understanding Amsterdam: Essays on Economic Vitality, City Life and Urban Form (pp. 143160). Amsterdam, the Netherlands: Het Spinhuis.

Lubwama, S. (2012). Mengo Demands Apology from Government over Buganda Riots. http://observer.ug/news-headlines/18749--mengo-demands-apology-from-government-over-buganda-riots

Lubwama, S. (2016). Sejusa Warns NRM on Coups, Uprisings. http://observer.ug/news-headlines/42899-sejusa-warns-nrm-on-coups-uprisings

Mabala, R. (2015). Public Order Management Act: Bad Law or Poor Enforcement? 
http://www.monitor.co.ug/SpecialReports/Public-Order-Management-Act-Bad-law-or-poor-enforcement-/-/688342/27876 98/-/ih56sez/-/index.html

Makara, S. (2010), Deepening Democracy through Multipartyism: The Bumpy Road to Uganda’s 2011 Elections. Africa Spectrum, 45, 81-94.

Mamdani, M. (2011). Walk to Work in a Historical Light. http://www.monitor.co.ug/News/National/-/688334/1149498/-/c2moiiz/-/index.html

Mamdani, M. (2012). What Walk to Work Needs to Succeed. http://www.observer.ug/index.php?option=com_content\&view=article\&id=16780:what-walk-to-work-needs-to-succeed\& catid=34:news\&Itemid=114

Marcuse, P. (2005). The “Threat of Terrorism” and the Right to the City. Fordham Urban Law Journal.

Masiga, F. (2012). Are Demonstrations the Only Language Left t to Ugandans? Sunday Monitor, 8 January 2012, Page 14. Kampala: Monitor Publications.

Mbazira, C. (2013). Service Delivery Protests, Struggle for Rights and the Failure of Democracy in South Africa and Uganda: Parallels and Divergences. SAJHR 29: 251-275

Miraftab, F., \& Wills, S. (2005). Insurgency and Spaces of Active Citizenship: The Story of Western Cape Anti-Eviction Campaign in South Africa. Journal of Planning Education and Research, 25, 200-217. http://dx.doi.org/10.1177/0739456X05282182

Mitchell, D. (2003). The Right to the City: Social Justice and the Fight for Public Space. New York: The Guilford Press.

Mivule, K. (2009). The Buganda Crisis, Technology, and Failure of Uganda’s News Media. https://mivuletech.wordpress.com/2009/09/14/the-buganda-crisis-technology-and-failure-of-uganda\%E2\%80\%99s-news$\underline{\text { media/ }}$

MRT (2009) Refugee Review Tribunal Australia. http://www.justice.gov/sites/default/files/eoir/legacy/2013/06/11/economic\%20conditions.pdf

Mugabe, F. (2016). How Government Has Controlled Communication during Polls. http://www.monitor.co.ug/Magazines/PeoplePower/How-government-has-controlled-communication-during-polls/-/68984 4/3085994/-/nhhwaxz/-/index.html

Mugagga, C. (2012). Why Is the NRM Government Not Paying What Is Due in Rents to Buganda? http://williamkituuka.blogspot.ug/2012/02/why-is-nrm-government-not-paying-what.html

Mugerwa, Y., \& Naturinda, S. (2011). Price Protesters Are Terrorists, Says Government. http://mobile.monitor.co.ug/News/-/691252/1217486/-/format/xhtml/-/d54g5g/-/index.html

Mugisha, A. (2011a). Walk to Work-Day One. http://activists4change.blogspot.ug/2011/04/walk-to-work-day-one.html

Mugisha, A. (2011b). Crackdown on Ugandan Activists When Walking to Work Became a Crime of Treason. http://activists4change.blogspot.com/2011 1001 archive.html

Mugisha, A. (2011c). On Monday We Walk. http://mbu-nugu.blogspot.ug/2011/04/on-monday-we-walk.html

Mukama, E. (2016). Free Kizza Besigye!—Ghetto President Bobi Wine. http://www.howwe.biz/news/celebrity/10739/free-kizza-besigye-bobi-wine

Mulumba, B. D. (2011). Uganda on the Eve of 50: The Legitimacy Challenge. Aid, Autocrats, Plunder and an Independence-Era Jinx. Africa Institute of South Africa. Briefing No. 50.

Muniini, M. (2016). Munini Mulera’s Letter on NRM 30 Years in Power. http://www.theinsider.ug/munini-mulera-letter-to-tingasinga-will-offer-an-opening-in-our-thought-pattern/

Murumba, G. (2011). Time Magazine Worried about Museveni’s Sanity. http://www.ugandacorrespondent.com/articles/2011/04/time-magazine-worried-about-museveni\%E2\%80\%99s-sanity/

Musaala, A. (2016). Fr. Musaala to Besigye: Did I Visit the Next PRESIDENT of Uganda? http://www.theinsider.ug/fr-musaala-to-besigye-did-i-visit-the-next-president-of-uganda/

Museveni, Y. (2007). Why I Support Mabira Forest Giveaway to Mehta Group. http://www.newvision.co.ug/new_vision/news/1166704/support-mabira-forest-away-mehta

Museveni, Y. (2011). Factors behind NRM’s Victory. New Vision Newspaper. http://www.newvision.co.ug/new_vision/news/1015309/factors-nrm-eur-victory

Mutaizibwa, E. (2012). Inspired by Arab Spring, A4C Ruffled Government Feathers. The Observer Newspaper. http://www.observer.ug/index.php?option=com content\&view=article\&id=18088:inspired-by-arab-spring-a4c-ruffled-gov t-feathers\&catid=34:news\&Itemid=114

Mwenda, A. (2012). Media Seduced by Museveni’s Mabira Decoy. 
http://www.ugfix.com/blogs/p/5013/media-seduced-by-musevenis-mabira-decoy

Nampewo, C. (2013). Saving Mabira Rainforest: Using Public Interest Litigation in Uganda to Save Mabira and Other Rainforests, 40 B.C. Envtl. Aff. L. Rev. 523. http://lawdigitalcommons.bc.edu/ealr/vol40/iss2/9 http://dx.doi.org/10.2139/ssrn.2202587

Naturinda, S. (2011). NRM Moves to Scrap Constitutional Bail. http://www.monitor.co.ug/News/National///688334/1162634//c1jfjlz///index.htm

Ndushabandi, C. (2016). Museveni Endorses Besigye Arrest; Threatens Tighter Social Media Controls. http://www.chimpreports.com/museveni-endorses-besigye-arrest-threatens-tighter-social-media-controls/

Nemeth, J. (2009). The Closed City: Downtown Security Zones and the Loss of Public Space. https://www.researchgate.net/publication/240642969_THE_CLOSED_CITY_DOWNTOWN_SECURITY_ZONES_AN D_THE_LOSS_OF_PUBLIC_SPACE

Nemeth, J. (2010). Security in Public Space: An Empirical Assessment of three US Cities. Environment and Planning A, 42, 2487-2507. http://dx.doi.org/10.1068/a4353

Njoroge, J. (2012). Museveni Says He Will Crush Lawless Civilians. http://www.monitor.co.ug/News/National/-/688334/1371806/-/aws30nz/-/index.html

Nyanzi, S. (2016). I Will Give Kayihura My Sumbusa If.... http://www.theinsider.ug/dr-stella-nyanzi-ill-give-kayihura-my-sumbusa-if/

Observer (2016). Rethink election crime preventer. http://observer.ug/viewpoint/editorial/42126-rethink-election-crime-preventers

Odoobo-Bichachi, C. (2012a). Political Jesters Telling Museveni What Others Can’t? The Observer Newspaper. http://www.observer.ug/index.php?option=com_content\&view=article\&id=17696:political-jesters-telling-museveni-whatothers-cant\&catid=37: guest-writers\&Itemid=66

Odoobo-Bichachi, C. (2012b). A4C Should Stay off Museveni’s Bloody Path. http://www.observer.ug/index.php?option=com content\&view=article\&id=18071:a4c-should-stay-off-musevenis-bloodypath\&catid=37: guest-writers\&Itemid=66

Odoobo-Bichachi, C. (2012c). Public Order Should Reflect All Interests. http://www.observer.ug/index.php?option=com_content\&view=article\&id=18735:-public-order-should-reflect-all-interest s\&catid=37:guest-writers\&Itemid=66

Okeowo, A. (2011). Uganda Burning. The New Yorker. http://www.newyorker.com/online/blogs/newsdesk/2011/05/uganda-burning.html

Oloka Onyango, J. (2014). Laws on Public Order, Gays and “Miniskirts” Are Birds of a Feather. http://observer.ug/index.php?option=com content\&view=article\&id=31100:laws-on-public-order-gays-and-miniskirts-are -birds-of-a-feather\&catid=37:guest-writers\&Itemid=66

Omach, P. (2010). Political Violence in Uganda: The Role of Vigilantes and Militias. Journal of Social, Political and Economic Studies, 35, 429-449.

Ostby, G. (2010). In-Migration, Inequality and Urban Violence: City Level Evidence from African and Asian Household Surveys. The Climate Change and Security Conference, Trondheim, 21-24 June 2010, 1-12.

Otim, D. (2011). Mama Mabira’ Vows to Take Museveni Head on. http://www.ugandacorrespondent.com/articles/2011/08/\%E2\%80\%98mama-mabira\%E2\%80\%99-vows-to-take-museveni$\underline{\text { head-on/ }}$

Red Pepper (2012). Opposition, Government See-Saw Accusations over Ariongo Murder. http://redpepper.co.ug/welcome/?p=33628

Red Pepper (2016). Notorious Gilbert Arinaitwe Who Smashed Besigye’s Car Back in Action. http://www.redpepper.co.ug/notorious-gilbert-arinaitwe-who-smashed-besigyes-car-back-in-action/

Republic of Uganda (2013). The Public Order Management Act, 2013. http://www.parliament.go.ug/new/images/stories/acts/2013/The\%20Public\%20order\%20management\%20act\%202013.pdf

Rubongoya, J. B. (2007). Regime hegemony in Museveni’s Uganda: Pax Musevenica. New York: Palgrave Macmillan. http://dx.doi.org/10.1057/9780230603363

Sassen, S. (2001). Global City: New York, London, Tokyo. Princeton: Princeton University Press. http://dx.doi.org/10.1515/9781400847488

Sassen, S. (2010). When the City Itself Becomes a Technology of War. Theory, Culture \& Society 2010 (SAGE, Los Angeles, London, New Delhi, and Singapore), 27, 33-50. http://dx.doi.org/10.1177/0263276410380938

Sassen, S. (2011). Why Riot Now? Newsweek Magazine. 
http://www.thedailybeast.com/newsweek/2011/08/14/why-did-britain-s-riots-happen-now.html

Semuwemba, A. K. (2009). Bimeeza Should Never Have Been Banned in Uganda. Abbey Kibirige Semuwemba Blog. https://semuwemba.com/2009/09/30/bimeza-should-never-have-been-banned-in-uganda/

Serunkuma, Y. (2016). Besigye’s Voters Must Be Missing the 1980s Museveni. http://observer.ug/viewpoint/42883-besigye-s-voters-must-be-missing-the-1980s-museveni

Soja, E. (1996). Thirdspace: Journeys to Los Angeles and Other Real-and-Imagined Places. Oxford: Blackwell

Ssekira, E. (2016). Report Details Link between Crime Preventers and NRM. http://observer.ug/news-headlines/42193-report-details-link-between-crime-preventers-and-nrm

Ssempala, R. (2016). State Attacks on Media Must Stop. http://observer.ug/viewpoint/42972-state-attacks-on-media-must-stop

Ssemuju, N. I. (2012). Musisi Wants to Be ED and Lord Mayor? http://allafrica.com/stories/201201200113.html

Ssenyonga, A., \& Lule, J. (2012). Besigye, A4C Officials at Kololo for Rally. New Vision. http://www.newvision.co.ug/new_vision/news/1300700/besigye-a4c-officials-kololo-rally

Sunrise (2015). Police Brutality; History of Impunity Erodes Public Trust. http://www.sunrise.ug/news/analysis/201501/police-brutality-history-of-impunity-erodes-public-trust.html

Suransky, C., Klooster, H. V., \& Seela, U. (2009). Uganda Riots Revisited: A Conversation with Emily Drani and John de Coninck. Pluralism Working Paper No. 4. Kosmopolis Institute, Utrecht, and Hivos, The Hague The Netherlands

Tabachnik, S. (2011). Bills, Bribery and Brutality: How Rampant Corruption in the Electoral System Has Helped Prevent Democracy in Uganda. Independent Study Project (ISP) Collection. Paper 1204. http://digitalcollections.sit.edu/isp_collection/1204

Taw, J. M., \& Hoffman, B. (1995). The Urbanization of Insurgency: The Potential Challenge to US Army Operations. Santa Monica: RAND.

Thompson, G. (1992). Colonialism in Crisis: The Uganda Disturbances of 1945. African Affairs, 91, 605-624.

Titeca, K., \& Onyango, P. (2012) The Carrot and the Stick: The Unlevel Playing Field in Uganda's 2011 Elections. In: F. Reyntjens, S. Vandeginste, \& M. Verpoorten (Eds.), L'Afrique des Grands Lacs. Annuaire 2011-2012 (pp. 111-130). Paris: L'Harmattan.

Tugume, G. (2016). Hope Mwesigye: Crime Preventers Operating like Interahamwe. http://www.chimpreports.com/hope-mwesigye-crime-preventers-operating-like-interahamwe/

Tumushabe, A. \& Rumanzi, P. (2016). Museveni Defends NRM Victory, Dismisses Rigging Allegations. http://www.monitor.co.ug/Elections/Museveni-defends-NRM-victory--dismisses-rigging-allegations-/-/2787154/3087654/ -/qrawhcz/-/index.html

Tumwine, A., \& Kato, J. (2016). Army, Police Search Vehicles to and Kampala. http://www.monitor.co.ug/Elections/Army--police-search-vehicles-to-and-from-Kampala/-/2787154/3087202/-/12a6g2f/-/ index.html

Twinoburyo, S. (2011a). Deconstructing Museveni’s Nairobi Interview. https://ugandaspeaks.wordpress.com/2011/05/01/deconstructing-museveni\%E2\%80\%99s-nairobi-interview/

Twinoburyo, S. (2011b). All Those Who Care for Uganda Should Adopt a Regime-Change Policy. https://ugandaspeaks.wordpress.com/2011/11/02/all-those-who-care-for-uganda-should-adopt-a-regime-change-policy/

Vasher, N. (2011). Museveni's Centralization of Power: The Political Economy of Development in Uganda. Electronic Theses and Dissertations. Paper 671. Denver, CO: University of Denver.

Walukuka, J. D. (2015). Uganda Journalists Union Condemns Andrew Lwanga’s Assault by Police. http://theinvestigatornews.com/uganda-journalists-union-condemns-andrew-lwanga\%E2\%80\%99s-assault-by-police-3/

Walusimbi, R. (2016). Relationship between Police, Media Should Be Professional. http://www.monitor.co.ug/OpEd/Commentary/Relationship-between-police-media-should-professional/-/689364/3105472 /-/roadv3z/-/index.html

WaMucoori, P. M. (2010). Kayihura, Kiboko Squad and the Sugar Thief. http://allafrica.com/stories/201007061242.html

Warigia, B., \& Camp, L. J. (2013). Protecting the Internet from Dictators: Technical and Policy Solutions to Ensure Online Freedoms. The Innovation Journal: The Public Sector Innovation Journal, 18.

Wasswa, S. (2015). Leave Gilbert Bwana Alone-Police Warns Media. http://www.chimpreports.com/leave-gilbert-bwana-alone-police-warns-media/

World Bank (2015). The Growth Challenge: Can Ugandan Cities Get to Work. Uganda Economic Update (5th ed.). Report Number 94622, Washington DC: World Bank. 
Young, I. M. (1990). Justice and the Politics of Difference. Princeton: Princeton University Press.

Zerah, M.-H., Lama-Rewal, T. S., Dupont, V., \& Chaudhuri, B. (2011). Right to the City and Urban Citizenship in the Indian Context. In: UNESCO, Urban Policies and the Right to the City in India Rights, Responsibilities and Citizenship (pp. 111). New Delhi: United Nations Educational, Scientific and Cultural Organization and Centre de Sciences Humaines. 